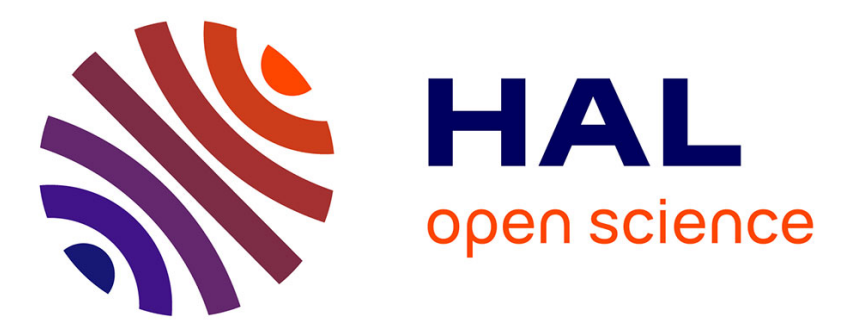

\title{
New organoselenides (NSAIDs-Se derivatives) as potential anticancer agents: Synthesis, biological evaluation and in silico calculations
}

Xianran He, Yousong Nie, Min Zhong, Shaolei Li, Xiaolong Li, Yi Guo, Zhenming Liu, Yangguang Gao, Fei Ding, Dan Wen, et al.

\section{To cite this version:}

Xianran He, Yousong Nie, Min Zhong, Shaolei Li, Xiaolong Li, et al.. New organoselenides (NSAIDs-Se derivatives) as potential anticancer agents: Synthesis, biological evaluation and in silico calculations. European Journal of Medicinal Chemistry, 2021, 218, pp.113384. 10.1016/j.ejmech.2021.113384 . hal-03188603

\section{HAL Id: hal-03188603 \\ https: / hal.sorbonne-universite.fr/hal-03188603}

Submitted on 2 Apr 2021

HAL is a multi-disciplinary open access archive for the deposit and dissemination of scientific research documents, whether they are published or not. The documents may come from teaching and research institutions in France or abroad, or from public or private research centers.
L'archive ouverte pluridisciplinaire HAL, est destinée au dépôt et à la diffusion de documents scientifiques de niveau recherche, publiés ou non, émanant des établissements d'enseignement et de recherche français ou étrangers, des laboratoires publics ou privés. 
New organoselenides (NSAIDs-Se derivatives) as potential anticancer agents: 8 9

\section{Synthesis, biological evaluation and in silico calculations}

Xianran $\mathrm{He}^{\mathrm{a}}$, Yousong Nie ${ }^{\mathrm{b}}$, Min Zhong ${ }^{\mathrm{a}}$, Shaolei $\mathrm{Li}^{\mathrm{c}}$, Xiaolong Lic ${ }^{\mathrm{c}}$, Yi Guo ${ }^{\mathrm{d}}$ Zhenming Liu ${ }^{\mathrm{d}}$, Yangguang Gao ${ }^{\mathrm{a}}$, Fei Ding ${ }^{\mathrm{a}}$, Dan Wen ${ }^{\mathrm{a}}$, Yongmin Zhang ${ }^{\mathrm{a}, \mathrm{e}_{*}}$

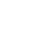

${ }^{a}$ Institute for Interdisciplinary Research, Jianghan University, Wuhan Economic and (1)

${ }^{b}$ School of Environmental Ecology and Biological Engineering, Wuhan Institute of Technology, LiuFang Campus, Guanggu $1^{\text {st }}$ road, Wuhan 430205, China

${ }^{c}$ Shenzhen Fushan Biological Technology Co., Ltd, Kexing Science Park A1 1005, Nanshan Zone, Shenzhen 518057, China

${ }^{d}$ State Key Laboratory of Natural and Biomimetic Drugs, School of Pharmaceutical Sciences, Peking University, Beijing 100191, China

${ }^{e}$ Institut Parisien de Chimie Moléculaire, CNRS UMR 8232, Sorbonne Université, 4 Place Jussieu, 75005 Paris, France 7

*Corresponding author: Yongmin Zhang 1

E-mail: yongmin.zhang@upmc.fr 


\section{Abstract:}

Herein we reported the synthesis of twenty new organoselenium compounds (2a-2j and $\mathbf{3 a - 3} \mathbf{j})$ based on the hybridization of nonsteroidal antiinflammatory drugs (NSAIDs) skeleton and organoselenium motif $\left(-\mathrm{SeCN}\right.$ and $\left.-\mathrm{SeCF}_{3}\right)$, the anticancer activity was evaluated against four types of cancer cell lines, Caco-2 (human colon adenocarcinoma cells), BGC-823 (human gastric cancer cells), MCF-7 (human breast adenocarcinoma cells), PC-3 (human prostatic cancer cells). Interestingly, the introduction of the $-\mathrm{SeCN}$ or $-\mathrm{SeCF}_{3}$ moiety in corresponding parent NSAIDs results in the significant effect on cancer cell lines. Moreover, the most active compound 3a showed $\mathrm{IC}_{50}$ values lower than $5 \mu \mathrm{M}$ against the four cancer cell lines, particularly to BGC-823 and MCF-7 with $\mathrm{IC}_{50}$ values of 2.5 and $2.7 \mu \mathrm{M}$, respectively. Furthermore, three compounds $\mathbf{3 a}, \mathbf{3 g}$ and $\mathbf{3 i}$ were selected to investigate their ability to induce apoptosis in BGC-823 cells via modulating the expression of anti-apoptotic Bcl-2 protein, pro-inflammatory cytokines (IL-2) and proapoptotic caspase- 8 protein. The redox properties of the NSAIDs-Se derivatives prepared herein were conducted by 2 , 2-didiphenyl-1-picrylhydrazyl (DPPH), bleomycin dependent DNA damage and glutathione peroxidase (GPx)-like assays. Finally, molecular docking study revealed that an interaction with the active site of thioredoxin reductase 1 (TrxR1) and predicted the anticancer activity of the synthesized candidates. Overall, these results could serve a promising launch point for further design of NSAIDs-Se derivatives as potential anticancer agents.

Keywords: selenium; selenocyanates; trifluoromethyl selenides; anticancer; in silico calculations 


\section{Introduction}

Non-steroidal anti-inflammatory drugs (NSAIDs) are a class of often chemically unrelated compounds commonly used to treat symptoms of inflammatory diseases such as osteoarthritis and rheumatoid arthritis, and are among the most widely used drugs worldwide $[1,2]$. In the field of cancer research, a large body of evidence from epidemiological and preclinical studies have shown that NSAIDs have used for chemo-preventive agents, especially in colorectal cancer (CRC) and prostate cancer [3-6]. Several modifications, based on NSAIDs scaffolds, have demonstrated stronger cytotoxicity and chemo-preventive than corresponding NSAID alone [7, 8]. NSAIDs framework modification has become a structure-based medicinal chemistry strategy to design novel anticancer agents in the past decades [9-12].

Selenium (Se) is an essential trace element that is of importance to human health and disease [13]. There are three main categories Se-containing compounds (inorganic, organic and selenoproteins) with potential pharmacological properties, the most developed and studied are the org-Se derivatives [14]. Different organic selenium compounds with diverse functional groups, including selenocyanates, selenoureas, heterocycles with endocyclic selenium, selenides and diselenides, have been reported to exhibit anticancer activity (Fig 1) [10, 15-21]. Although the mechanisms that underlie the potential anticancer activity of seleno compounds are very diverse (including protein modification, cell growth arrest, anti-angiogenic effects, etc) [22], the most frequent one is the reduction of oxidative stress through the elimination of free radicals [23-25].

In the previous study, the modification of NSAID framework with Se functionalities is the novel celecoxib-Se derivatives, which exhibited anti-inflammatory and anti-cancer activity $[11,12]$. Very recently, we have reported the synthesis of a series of novel NSAIDs-Selenium derivatives and screened their anticancer activity by vitro study, the modification of NSAIDs scaffolds with Se functionalities (-SeCN, -Se-Se-, $-\mathrm{SeCF}_{3}$ ) demonstrated potent inhibition of human tumor cell [21, 26-27]. Along with the reports that support the modification of NSAIDs scaffolds with Se functionalities and in continuation of our research program 
1 on design and synthesis of new NSAIDs-Se derivatives as potential anticancer agents $2[28,29]$, twenty new NSAIDs-SeCN and $\mathrm{NSAIDs}_{-} \mathrm{SeCF}_{3}$ derivatives were designed

3 by the incorporation of an appropriate Se moiety into various NSAIDs with a general 4 model consist of three essential fragments in their molecular: i) NSAIDs fragment; ii) 5 electron donating group $(\mathrm{X}=\mathrm{NH}, \mathrm{O}, \mathrm{Se})$; iii $)$ functional group bearing the $\mathrm{Se}$ atom 6 (Fig 2). Their anticancer activities against the human cancer cell lines Caco-2, $7 \quad$ BGC-823, MCF-7 and PC-3 in vitro using the MTT assay. Three compounds 3a, 3g 8 and $3 \mathbf{i}$ were selected to test the protein expression levels of Bcl-2, IL- 8 and caspase- 8 9 biomarkers in BGC-823 cells. Furthermore, the antioxidant potential of the 10 compounds was investigated by employing DPPH, bleomycin-dependent DNA 11 damage and GPx-like assays. Finally, TrxR1 (Thioredoxin Reductase) was selected as 12 docking protein in order to predict the target and anticancer activity of the prepared 13 NSAIDs-Se hybrid compounds.<smiles>C=C(c1cccc(O)c1)c1cc([Se])c(OC)c(OC)c1</smiles>

Methyl(phenyl)selane [15]<smiles>O=C1c2ccccc2[Se](=O)N1c1ccccc1</smiles>

Ebselen [18]

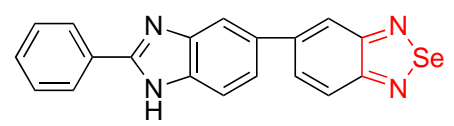

Selenadiazole [16]<smiles>O=S(CCCCN=C=[Se])Cc1ccc(F)cc1</smiles>

Isoselenocyanate [19]<smiles>O=C(O)CC[Se][Se][Se]CCC(=O)O</smiles>

Diselenides [17]<smiles>Cc1cc(=O)oc2cc(NC(=[Se])Nc3ccccc3)ccc12</smiles>

Selenium-Urea [20]<smiles>CC(=O)Oc1ccccc1C(=O)NCC[Se]#N</smiles>

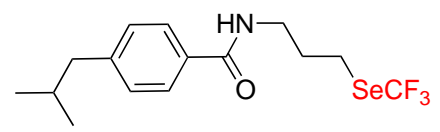

I bupr ofen-SeCF ${ }_{3}$ Derivative [21]

15 Fig. 1. Organic selenium compounds previously reported with anticancer activity 


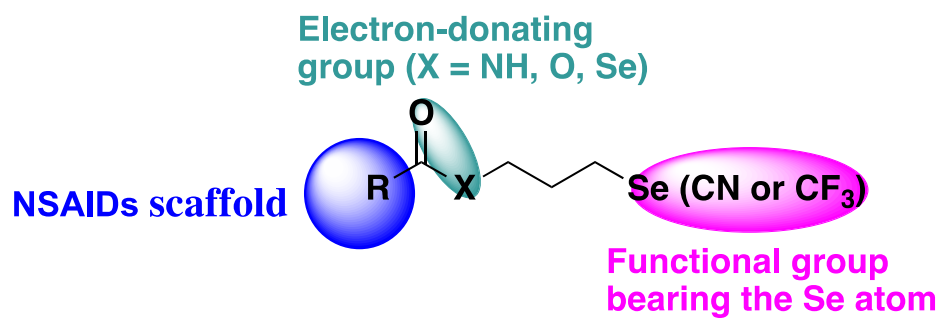

Fig. 2. General pattern of NSAIDs-Se derivatives with anticancer activity

\section{Results and Discussion}

\subsection{Chemistry}

The synthetic route for target compounds $(\mathbf{2} \mathbf{a}-\mathbf{2} \mathbf{j}$ and $\mathbf{( 3 a - 3 j})$ were prepared as outlined in Scheme $\mathbf{1}$ according to the procedure described in the literature

9 with some modifications [30]. Compound 1 was obtained by the nucleophilic substitution of $-\mathrm{Br}$ atom in 3-bromo-1-propanol by - $\mathrm{SeCN}$, using $\mathrm{KSeCN}$ as

11 nucleophilic donor, in acetonitrile as solvent and under a nitrogen atmosphere.

12 The selenocyanate derivatives $\mathbf{2 a - 2 j}$ were readily obtained by reacting

13 3-selenocyanatopropan-1-ol with commercially available NSAIDs in the present

14 of DCC and DMAP as condensation agent. The trifluoromethyl selenide derivatives 15 were obtained by conducting corresponding selenocyanate derivative with 16 trimethyl(trifluoromethyl)silane $\left(\mathrm{TMSCF}_{3}\right)$ in the present of tetrabutylammonium 17 fluoride (TBAF) as catalyst to afford 3a-3j in good yields (yield $\geq 80 \%$ ) (Scheme 1) 18 [31].

19 The purity of all final compounds was $95 \%$ or higher and their chemical 20 structures were characterized using ${ }^{1} \mathrm{H}$ NMR, ${ }^{13} \mathrm{C}$ NMR, ${ }^{19} \mathrm{~F}$ NMR and HRMS (ESI). 


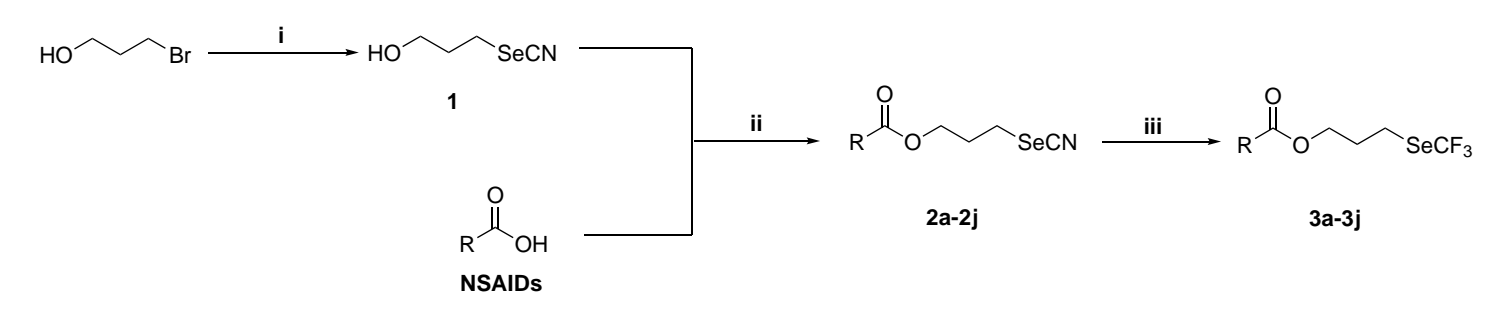

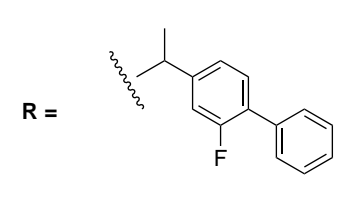

2a, 3a

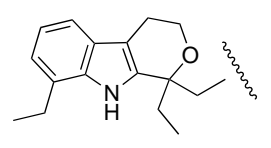

$2 e, 3 e$

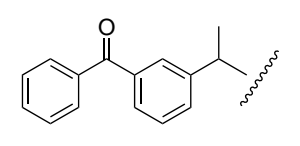

2i, 3i

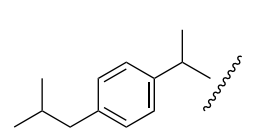

$2 b, 3 b$

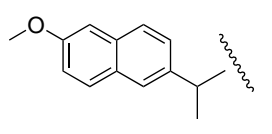

2f, $3 f$

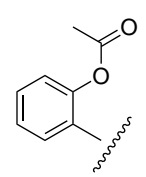

2j, 3j

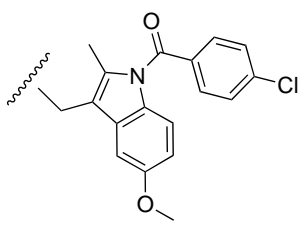

2c, 3c

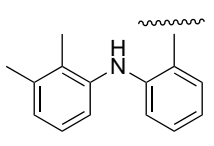

2d, 3d

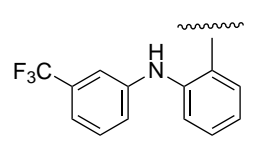

$2 g, 3 g$

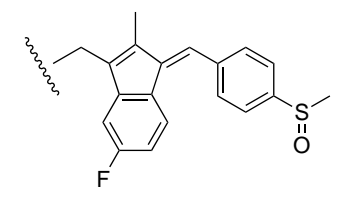

2h, 3h

Scheme 1. i) $\mathrm{KSeCN}, \mathrm{CH}_{3} \mathrm{CN}, 80{ }^{\circ} \mathrm{C}, 24 \mathrm{~h}, 90 \%$; ii) DCC, DMAP, DCM, $25{ }^{\circ} \mathrm{C}, 16$ h 70\% - 90\%; iii) TBAF, $\mathrm{TMSCF}_{3}$, THF, $25^{\circ} \mathrm{C}, 2$ h, $80 \%-85 \%$.

\subsection{Cell viability assay}

The synthesized compounds (3a, 3g and $\mathbf{3 i}$ ) and selected patent NSAIDs (Aspirin, Ibuprofen and Naproxen) were evaluated for their anticancer activity towards human tumor cell lines: Caco-2 (human epithelial colorectal adenocarcinoma cell line), BGC-823 (human gastric cancer cell line), MCF-7 (human breast 10 adenocarcinoma cell line) and PC-3 (human prostate cancer cell line). In vitro 11 evaluation of anticancer activity was determined by the MTT assay. 5-Fluorouracil 12 was used as positive control because it is commonly used in adjuvant and palliative cancer chemotherapy.

Overall, the $\mathrm{IC}_{50}$ values obtained and summarized in Table $\mathbf{1}$ shows that all of the tested organoselenium compounds exhibit growth inhibition in all cancer cell lines, while the selected patent NSAIDs (Aspirin, Ibuprofen and Naproxen) are inactive against all cells even in the maximum dose of $50 \mu \mathrm{M}$. The $\mathrm{IC}_{50}$ values obtained for the 
1 NSAIDs-Se derivatives $\mathbf{2 j}$, $\mathbf{3 b}$ and $\mathbf{3 f}$, showed that introduction of the $-\mathrm{SeCN}$ or

$2-\mathrm{SeCF}_{3}$ moiety in corresponding parent NSAIDs scaffold result in the significant

3 effect on cancer cell line.

4 An overview analysis of the $\mathrm{IC}_{50}$ values obtained and summarized in Table 1

5 showed that most of the $\mathrm{NSAIDs}-\mathrm{SeCF}_{3}$ derivatives presented better effectiveness

6 than NSAIDs-SeCN derivatives and previous reported NSAIDs-diselenides

7 derivatives against all four cancer cell lines [27]. Furthermore, the most active

8 compounds of these two series are NSAIDs-SeCF 3 derivatives $\mathbf{3 a}, \mathbf{3 g}$ and $\mathbf{3 i}$. These

9 three compounds show $\mathrm{IC}_{50}$ values below $10 \mu \mathrm{M}$ in all of tested cancer cell lines.

10 Compound 3a emerges the most potent agent with $\mathrm{IC}_{50}$ values below $5 \mu \mathrm{M}$ in all

11 cancer cell lines and with remarkable anticancer activity against BGC-823 $(2.5 \mu \mathrm{M})$

12 and MCF-7 (2.7 $\mu \mathrm{M})$.

13 Interestingly, among the tested compounds, most of the $\mathrm{NSAIDs}_{-} \mathrm{SeCF}_{3}$ 14 derivatives except $\mathbf{3 f}$ and $\mathbf{3 h}$ displayed $\mathrm{IC}_{50}$ values below $10 \mu \mathrm{M}$ against MCF-7 cells.

15 The anticancer activity of NSAIDs with trifluoromethyl selenides moiety is better 16 than corresponding NSAIDs with selenocyanates moiety, considering the lipophilicity 17 and electron withdrawing effect. 


\section{Table 1}

2 Cytotoxic activity expressed by $\mathrm{IC}_{50}$ of NSAIDs-Se hybrid compounds (2a-2 $\mathbf{j}$ and

$3 \mathbf{3 a - 3 j}$ ) on different cancer cell lines.

\begin{tabular}{|c|c|c|c|c|}
\hline \multirow[t]{2}{*}{ Compound } & \multicolumn{4}{|c|}{$\mathrm{IC}_{50}(\boldsymbol{\mu M})^{\mathrm{a}}$} \\
\hline & Caco2 & BGC-823 & MCF-7 & PC-3 \\
\hline Aspirin $^{b}$ & $>50$ & $>50$ & $>50$ & $>50$ \\
\hline Ibuprofen $^{b}$ & $>50$ & $>50$ & $>50$ & $>50$ \\
\hline Naproxen ${ }^{b}$ & $>50$ & $>50$ & $>50$ & $>50$ \\
\hline $\mathbf{2 a}$ & $27.5 \pm 3.1$ & $29.4 \pm 3.3$ & $22.4 \pm 2.1$ & $19.7 \pm 1.8$ \\
\hline $2 \mathbf{b}$ & $14.5 \pm 1.3$ & $24.5 \pm 2.3$ & $19.5 \pm 1.7$ & $22.5 \pm 3.4$ \\
\hline $2 c$ & $32.4 \pm 3.5$ & $35.5 \pm 3.4$ & $29.3 \pm 1.9$ & $21.8 \pm 1.6$ \\
\hline 2d & $17.2 \pm 1.4$ & $22.1 \pm 1.9$ & $17.4 \pm 2.1$ & $33.2 \pm 3.3$ \\
\hline $2 \mathrm{e}$ & $11.5 \pm 1.1$ & $21.4 \pm 2.3$ & $14.4 \pm 1.3$ & $31.4 \pm 3.0$ \\
\hline $2 f$ & $21.5 \pm 2.4$ & $17.3 \pm 2.3$ & $32.8 \pm 3.1$ & $22 \pm 1.7$ \\
\hline $2 g$ & $8.4 \pm 0.8$ & $13.7 \pm 1.2$ & $14.2 \pm 1.1$ & $7.5 \pm 1.3$ \\
\hline $2 \mathrm{~h}$ & $28.6 \pm 2.5$ & $17.5 \pm 1.8$ & $31.3 \pm 3.2$ & $22.3 \pm 2.1$ \\
\hline $2 \mathbf{i}$ & $19.7 \pm 2.0$ & $12.6 \pm 1.4$ & $8.3 \pm 0.7$ & $12.6 \pm 1.5$ \\
\hline $2 \mathbf{j}$ & $14.5 \pm 1.8$ & $17.3 \pm 2.3$ & $8.9 \pm 0.8$ & $11.2 \pm 2.3$ \\
\hline $3 \mathbf{a}$ & $4.5 \pm 0.6$ & $2.5 \pm 0.4$ & $2.7 \pm 0.2$ & $3.3 \pm 0.3$ \\
\hline $3 b$ & $9.5 \pm 0.6$ & $14.3 \pm 1.5$ & $9.9 \pm 0.7$ & $10.4 \pm 2.0$ \\
\hline $3 c$ & $10.5 \pm 1.1$ & $7.3 \pm 0.5$ & $9.3 \pm 0.7$ & $7.8 \pm 0.7$ \\
\hline $3 d$ & $13.3 \pm 1.6$ & $19.6 \pm 2.1$ & $8.5 \pm 1.3$ & $24.5 \pm 2.3$ \\
\hline $3 \mathbf{e}$ & $10.4 \pm 1.3$ & $18.5 \pm 1.7$ & $8.7 \pm 0.7$ & $19.7 \pm 1.9$ \\
\hline $3 f$ & $16.3 \pm 1.4$ & $10.8 \pm 0.8$ & $12.4 \pm 0.4$ & $18.4 \pm 1.7$ \\
\hline $3 g$ & $3.5 \pm 1.8$ & $2.7 \pm 1.8$ & $4.2 \pm 1.8$ & $5.8 \pm 1.8$ \\
\hline $3 h$ & $16.4 \pm 2.2$ & $14.4 \pm 1.6$ & $19.6 \pm 2.4$ & $11.6 \pm 0.7$ \\
\hline $3 \mathbf{i}$ & $9.5 \pm 1.1$ & $4.8 \pm 0.3$ & $6.5 \pm 1.8$ & $8.8 \pm 1.3$ \\
\hline $3 \mathbf{j}$ & $11.3 \pm 1.5$ & $8.2 \pm 0.7$ & $7.7 \pm 0.6$ & $10.4 \pm 0.9$ \\
\hline $5-F u^{c}$ & $7.8 \pm 3.1$ & $15.4 \pm 1.8$ & $12.3 \pm 2.2$ & $9.5 \pm 1.1$ \\
\hline
\end{tabular}

$4{ }^{\mathrm{a}} \mathrm{IC}_{50}$ values $( \pm \mathrm{SD})$ of $\%$ cell viability determined by the MTT assay of three 5 repititions

$6 \quad{ }^{\mathrm{b}}$ Patent NSAIDs

$7 \quad{ }^{\mathrm{c}}$ Standard benchmark compound.

9 2.3. Detection of Bcl-2, IL-2 and caspase- 8 protein expression levels in BGC-823 $10 \quad$ cells.

11 In order to further understand the possibly addressed signaling pathways and 12 obtain hints on the mode(s) of action of the synthesized compounds, we selected the 13 most promising derivatives $\mathbf{3 a}, \mathbf{3 g}$ and $\mathbf{3 i}$ and investigated their ability to induce 
1 apoptosis in BGC-823 cells via modulation the expression of anti-apoptotic Bcl-2

2 protein, pro-inflammatory cytokines (IL-2) and proapoptotic caspase-8 protein.

3 As shown in Fig 3, all the three compounds were able to downregulate the 4 expression of Bcl-2 and upregulate the expression of IL-2 and Caspase-3 in BGC-823 5 cells compared with untreated cells. Interestingly, compound $\mathbf{1 g}$ downregulate over $650 \%$ the expression levels of Bcl-2 compared to untreated cells. Further more, 7 compounds $1 \mathrm{~g}$ and $1 \mathrm{~h}$ modulate the Caspase- 8 level at most 1.5 fold increase in 8 expression when compared to the untreated control cells. From these results, it's likely 9 that organic selenocyanates may induced apoptosis to inhibit tumor cells growth, and 10 in line with the first selenocyanate (1,4-phenylenebis(methylene)selenocyanate) 11 which proved to be effective against prostate and oral carcinoma cells [32, 33].
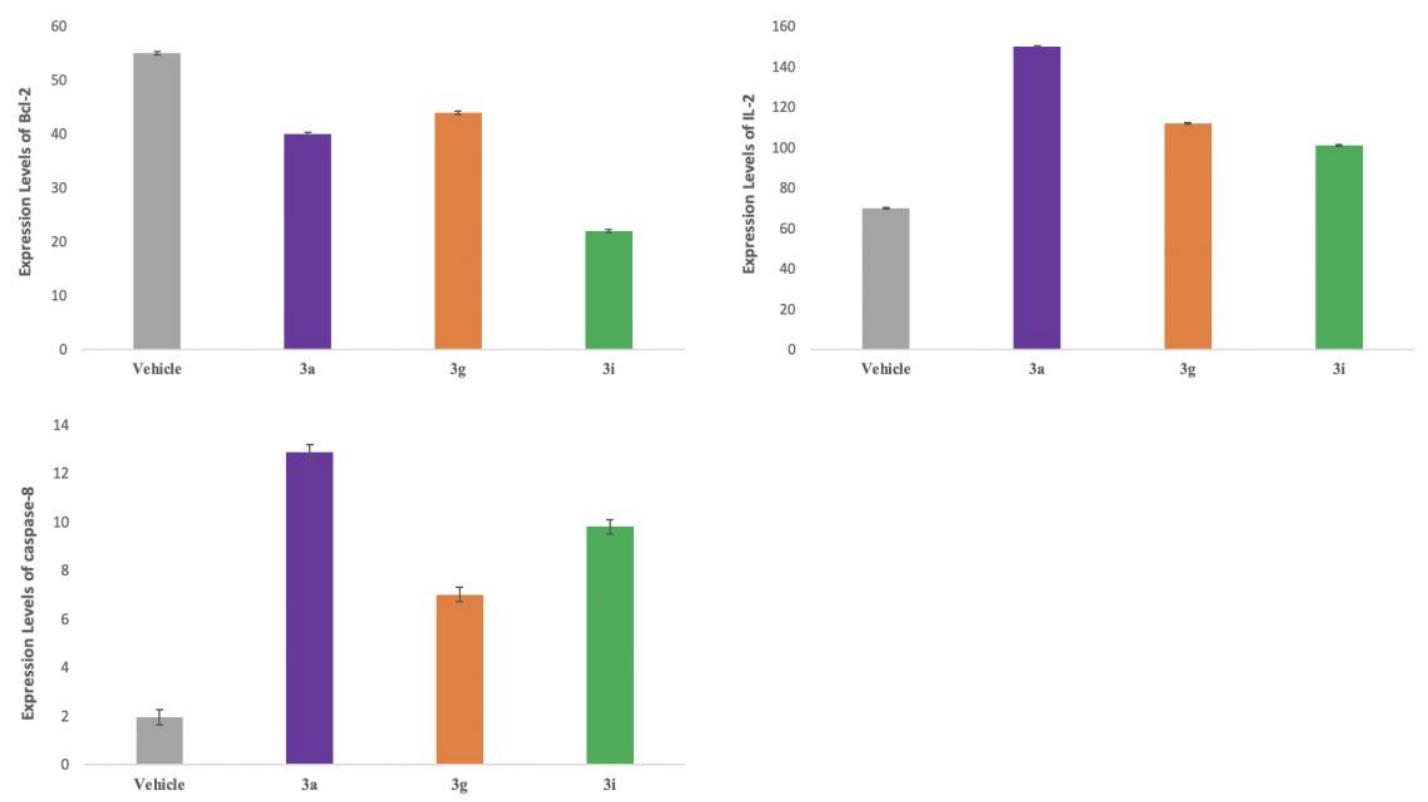

14 Fig. 3. Protein expression levels of Bcl-2, IL-2 and caspase-8 in BGC-823 cells after

$1548 \mathrm{~h}$ incubation with compounds $\mathbf{3 a}, \mathbf{3} \mathbf{g}$ and $\mathbf{3 i}$ at their respective $\mathrm{IC}_{50} \mathrm{~s}$ compared to 16 untreated cells.

\subsection{Antioxidant assay}

Reactive oxygen species (ROS) is a broad term that encompasses both oxygen

20 free radicals, which have unpaired electrons, such as superoxide, hydroxyl and 21 peroxyl as well as oxidizing agents that are not free radicals such as hydrogen 22 peroxide, hypochlorous acid and ozone [34]. ROS play essential roles in altering 
1 protein structure, thereby changing its function and participate in many pathological

2 processes [35, 36]. Various human diseases, including different types of cancer, are

3 associated with a disturbed intracellular redox balance and oxidative stress (OS) [37,

4 38].

5 Owing to the fact that a number of synthetic organoselenium compounds have been synthesized for their use as redox-modulators in the last few years [39-41], the antioxidant activity of compounds (3a, 3g, 3i) are further estimated employing different biochemical assays such as DPPH, bleomycin-dependent DNA damage and Gpx-like assays [42, 43].

2.4.1. Radical scavenging capacity (DPPH) assay.

There are various methods which have been developed to provide fast prediction and 3d.

\subsubsection{Bleomycin DNA damage assay.}

Bleomycin (BLM) is a complex of related glycopeptide from Streptomyces verticillus, it inhibits DNA metabolism and is used as an antineoplastic, especially for 
1 solid tumors [47]. The bleomycin-iron DNA damage assay has been routinely used as

2 a preliminary method to test potential of drugs and organic selenium compound [48,

3 49]. As shown in Table 2, compounds 3a, 3g and 3i induced DNA degradation

4 significantly more than other tested compounds.

5

\section{Table 2}

7 Redox modulation activity of NSAID-Se hybrid compounds.

\begin{tabular}{|c|c|c|c|}
\hline \multirow{3}{*}{$\begin{array}{l}\text { Compd. } \\
\text { No. }\end{array}$} & \multirow{2}{*}{\multicolumn{2}{|c|}{$\begin{array}{l}\text { DPPH } \\
\text { assay }\end{array}$}} & \multirow{4}{*}{$\begin{array}{l}\text { Bleomycin-dependent DNA damage } \\
\text { assay } \\
\text { Absorbance }\end{array}$} \\
\hline & & & \\
\hline & Inhibition & Fold & \\
\hline & $\%$ & & \\
\hline Vitamin C & $96.4 \pm 1.3$ & 1 & $297 \pm 2.83$ \\
\hline $\mathbf{2 a}$ & $17.2 \pm 1.4$ & 0.2 & $86.5 \pm 0.54$ \\
\hline $2 \mathbf{b}$ & $31.2 \pm 2.8$ & 0.3 & $60.3 \pm 0.43$ \\
\hline $2 c$ & $44.3 \pm 36$ & 0.4 & $72.4 \pm 0.33$ \\
\hline 2d & $29.6 \pm 2.7$ & 0.3 & $95.6 \pm 1.82$ \\
\hline $2 e$ & $30.4 \pm 1.4$ & 0.3 & $69.4 \pm 0.42$ \\
\hline $2 f$ & $24.6 \pm 1.3$ & 0.2 & $81.6 \pm 0.48$ \\
\hline $2 \mathrm{~g}$ & $51.5 \pm 1.2$ & 0.5 & $76.1 \pm 0.39$ \\
\hline $2 \mathbf{h}$ & $45.7 \pm 4.3$ & 0.5 & $91.3 \pm 1.63$ \\
\hline $2 \mathbf{i}$ & $57.1 \pm 4.3$ & 0.6 & $67.6 \pm 1.83$ \\
\hline $2 \mathrm{j}$ & $27.3 \pm 3.1$ & 0.3 & $78.3 \pm 1.17$ \\
\hline $3 \mathbf{a}$ & $73.5 \pm 4.1$ & 0.8 & $119.4 \pm 1.78$ \\
\hline $3 \mathbf{b}$ & $48.5 \pm 2.8$ & 0.5 & $95.7 \pm 2.27$ \\
\hline $3 c$ & $36.6 \pm 2.2$ & 0.4 & $62.6 \pm 1.18$ \\
\hline 3d & $23.3 \pm 1.2$ & 0.3 & $77.6 \pm 1.40$ \\
\hline $3 \mathbf{e}$ & $41.4 \pm 2.2$ & 0.4 & $86.4 \pm 1.21$ \\
\hline $3 \mathbf{f}$ & $37.0 \pm 1.0$ & 0.4 & $91.4 \pm 1.13$ \\
\hline $3 \mathbf{g}$ & $68.6 \pm 2.6$ & 0.7 & $114.8 \pm 2.32$ \\
\hline $3 \mathbf{h}$ & $44.9 \pm 2.3$ & 0.5 & $73.7 \pm 1.12$ \\
\hline
\end{tabular}




\begin{tabular}{llll} 
3i & $66.3 \pm 2.6$ & 0.7 & $128.4 \pm 1.38$ \\
$\mathbf{3 j}$ & $32.4 \pm 1.8$ & 0.4 & $88.7 \pm 1.32$ \\
\hline
\end{tabular}

1

\subsubsection{Glutathione peroxidase-like activity assay.}

3

Glutathione peroxidase (GPx) is a selenoenzyme that protects cells by catalyzing the reduction of peroxides with the stoichiometric reductant glutathione (GSH) [50, 51]. The potential antioxidant activity of all of the NSAIDs-Se derivatives were estimated using NADPH-reductase coupled assay [52]. The GPx activity of the synthesized compounds was estimated by the decrease in absorbance $(340 \mathrm{~nm})$ due to the oxidation of NADPH to $\mathrm{NADP}^{+}$. Ebselen was used as the positive control.

As shown in Fig. 4, compounds $2 \mathbf{h}, \mathbf{2 i}, \mathbf{3 b}, \mathbf{3 e}, \mathbf{3 h}$ and $\mathbf{3 i}$ displayed a GPx-like activity better than other derivatives. Compound $\mathbf{3 h}$ was the most active derivatives in this assay, up to 3 fold to the GPx mimetic ebselen.

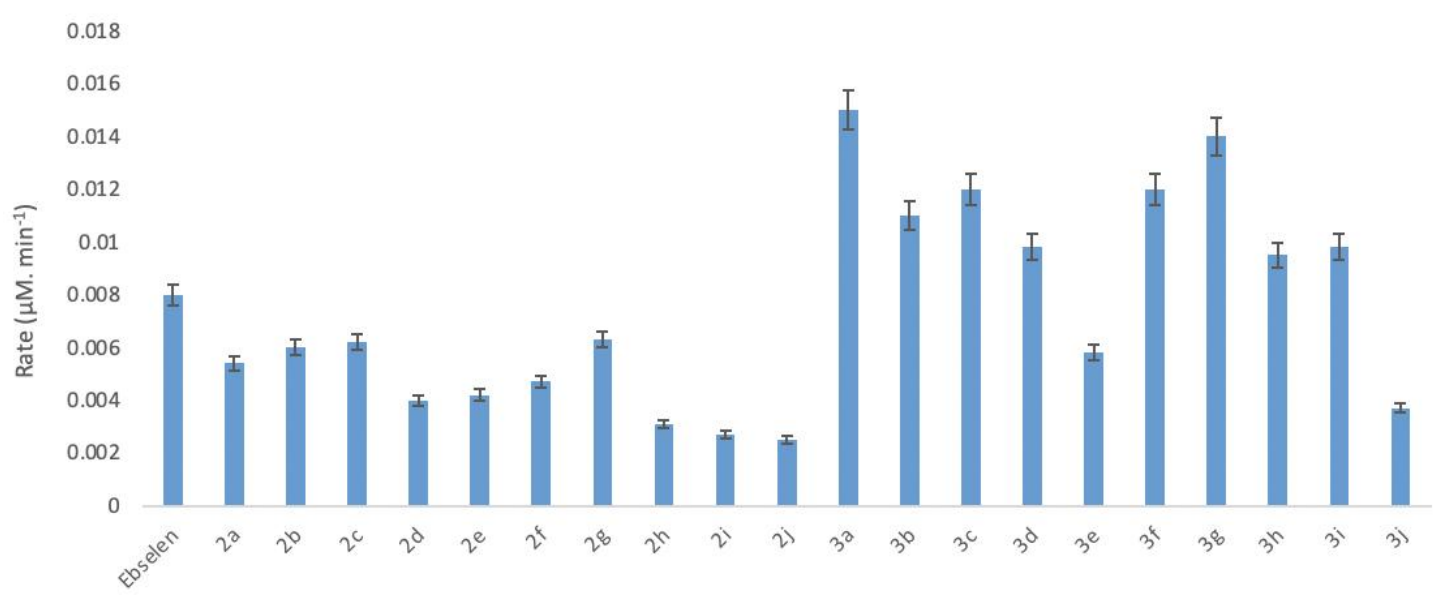

Fig. 4. GPx-like activity assay of NSAID-Se hybrid compounds in $\mu \mathrm{M}$. $\mathrm{Min}^{-1}$.

\subsection{Docking Studies}

The interaction mode between our organoselenium compounds and Mammalian TrxR1 protein, which is closely related to the anticancer activity of compounds, need to be further explained by docking studies. TrxR1 consists of four monimers which have the FAD and NAD binding domains at the N-terminal and the dimerization interface domain at the flexible C-terminal side [53-55]. In the insufficiency of human 
1 3D structure complexes cocreytallized of human TrxR1 with inhibitors, flexible 2 docking was considered to be a practical method according to the literature [56]. With 3 good antioxidant activity, compounds $\mathbf{3 a}, \mathbf{3 g}$ and $\mathbf{3 i}$ were docked into the TrxR1 4 protein (PDB id: 1H6V) using Flexible Docking Protocol as reported in the literature 5 [56]. All three compounds showed acceptable docking results (Table 3-5 are reported 6 in the supporting information). It is thought that the distance between the selenium atom and Cys497/Cys498 is closely related to the accessibility of cysteine thiol 8 attacking the selenide. Therefore, for each structure, the selection of the best pose of 9 the docking results is related to the value of binding energy, while the distance would 10 also be focused. Among the three compounds, Pose 3 of $\mathbf{3 a}$ showed a better docking 11 results with the relatively good value of -CDOCKER energy $(30.184 \mathrm{kcal} / \mathrm{mol})$. 12 Meanwhile, the distance between the selenium atom and Cys498 was only $4.388 \AA$ 13 (Table 3, Pose 3). This good result may be related to the key hydrogen bond 14 interaction between the Fluorine on benzene group and His472 (2.11 A). In addition, 15 3a also formed two hydrogen bonds, which are the hydrogen bond between $-\mathrm{SeCF}_{3}$ 16 group and His472 (2.97 $\AA$ ) and the hydrogen bond between the oxygens of ester 17 groups and Cys475 (2.62 ̊) (Figure 5). For compound 3g, the interactions shown in pose 3 are not only the hydrogen bonds, but also a $\pi-\pi$ stacking between the benzene 19 ring and Phe406 (Figure 6). However, the distance between the selenium atom and 20 Cys497/Cys498 is far than 3a (Table 4). For 3i, although there are multiple hydrogen 21 bonds near the carbonyl group, the long distance between the selenium atom and Cys497/Cys498 may be related to the long linear structure of the whole compound

23 (Figure 7, Table 5). This structure makes it difficult for molecule to penetrate into the 24 pocket as a whole, thus affecting the interaction between molecule and protein. 


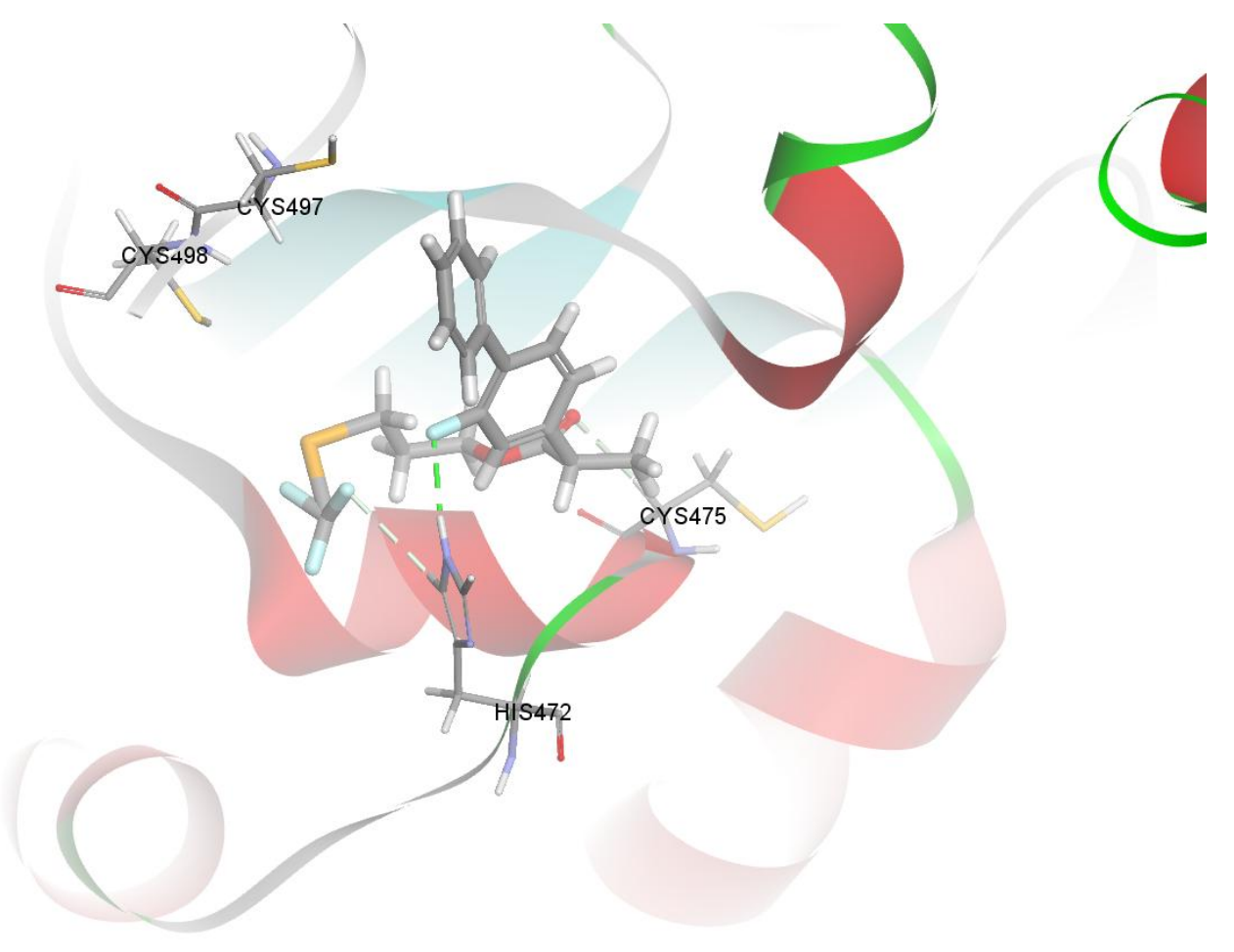

2 Fig. 5. The pose 3 of 3a. Three interactions are shown: hydrogen bonding between the 3 Fluorine on benzene group and His472 (2.11 $\AA$ ); hydrogen bonding between the 4 Fluorine of -SeCF3 group and His472 (2.97 $\AA$ ) and hydrogen bonding between the 5 oxygens of ester groups and Cys475 (2.62 ̊).

6

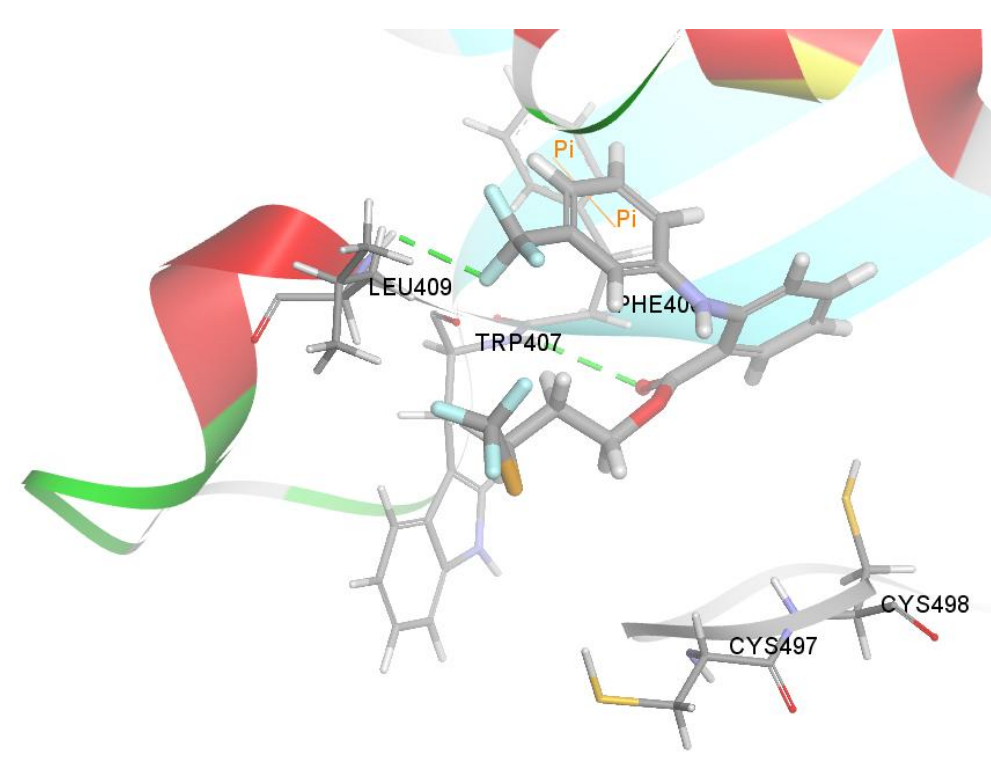

8 Fig. 6. The pose 3 of $\mathbf{3 g}$. Three interactions are shown: hydrogen bonding between the 9 Fluorine of -CF3 group and LEU409 (2.57 $\AA$ ); hydrogen bonding between the 10 oxygens of ester groups and $\operatorname{Trp} 407$ (2.78 $\AA$ ) and $\pi$ - $\pi$ stacking between the benzene 11 ring and Phe406. 


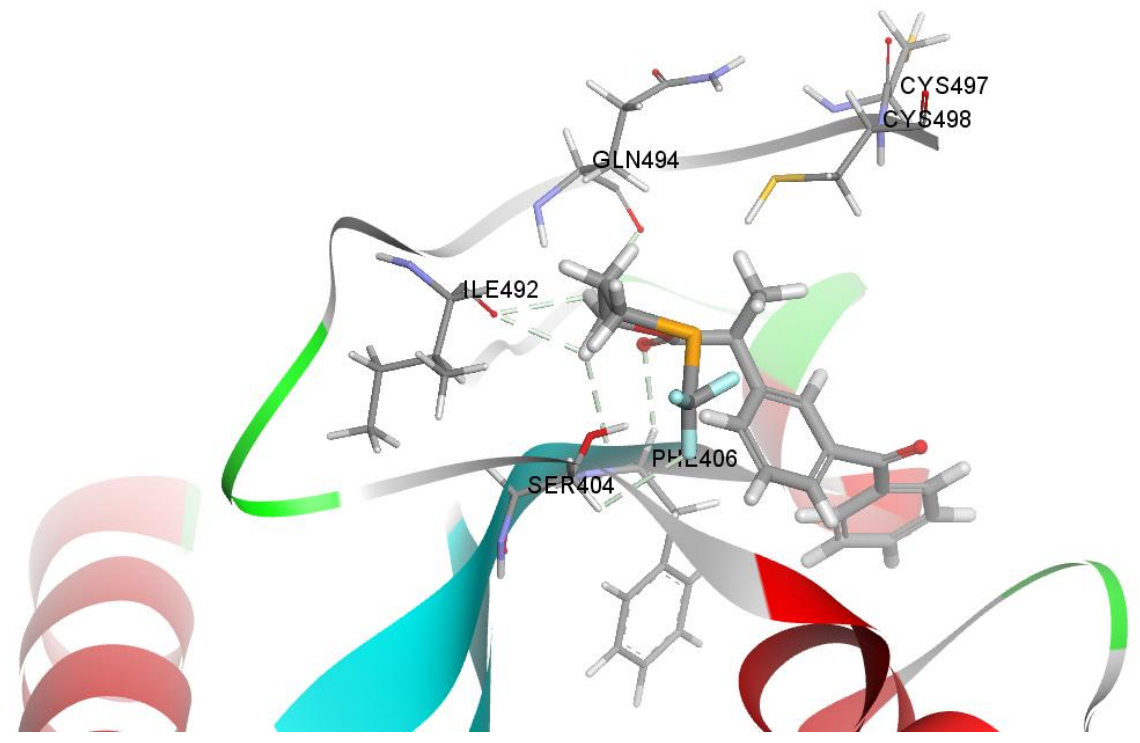

2 Fig. 7. The pose 4 of 3i. Three interactions are shown: hydrogen bonding between the 3 Fluorine of -SeCF3 group and Ser404 (2.80 A); hydrogen bonding between the two hydrogens on carbonyl group $\alpha$ postion and Ile492 (2.54 А, $2.64 \AA$ ) or Gln494 (2.90 $\AA$ ); hydrogen bonding between the oxygens of ester groups and Phe406 (2.46 $\AA$ ).

\section{Conclusions}

In summary, twenty new organoselenium compounds were synthesized and characterized. Four human cell lines (Caco-2, BGC-823, MCF-7 and PC-3) were selected to test anticancer activity of the compounds. Compound 3a showed most

11 potent anticancer activity with $\mathrm{IC}_{50}$ values below $5 \mu \mathrm{m}$ against four cancer cell lines.

12 Moreover, three compounds were selected to test their ability to induce apoptosis in

13 BGC-823 cells via modulation the expression of anti-apoptotic Bcl-2 protein, 14 pro-inflammatory cytokines (IL-2) and proapoptotic caspase-8 protein. Compounds

$15 \mathbf{3 a}, \mathbf{3 g}$ and $\mathbf{3 i}$ were able to downregulate the expression of $\mathrm{Bcl}-2$ and upregulate the expression of IL-2 and Caspase-8 in BGC-823 cells. Furthermore, most of the organoselenium compounds exhibited moderate to good CPx-like activity compared to ebselen. Finally, in flexible docking study performed into TrxR1 enzyme, compound 3a showed a promising binding energies and binding mode that the distance between the selenium atom and Cys497/Cys498. At this point, compound 3a may act as TrxR inhibitors. 


\section{Experimental section}

4.1. General methods

All chemical reagents for the synthesis of the compounds were purchased from Macklin (Shanghai, China) or TCI (Shanghai, China) and used without further purification unless stated otherwise. Thin-layer chromatography (TLC) was performed on aluminium pre-coated sheets (E. Merck Silica gel 60 F254). Melting points were recorded on an Electrothermal apparatus and are uncorrected. NMR spectra were recorded in $\mathrm{CDCl}_{3}$ on a Bruker Avance $400 \mathrm{MHz}$ (for ${ }^{1} \mathrm{H}$ ), $100 \mathrm{MHz}$ (for ${ }^{13} \mathrm{C}$ ) and $376 \mathrm{MHz}$ (for ${ }^{19} \mathrm{~F}$ ) spectrometer with $5 \mathrm{~mm}$ PABBO probe. The following abbreviations were used to explain the multiplicities: $\mathrm{s}=$ singlet, $\mathrm{d}=$ doublet, $\mathrm{t}=$ triplet, $\mathrm{q}=$ quartet, and $\mathrm{m}=$ multiplet. Chemical shifts $(\delta)$ are reported in parts per million (ppm) downfield from TMS and the coupling constants $(J)$ are expressed in Hertz (Hz). High-resolution MS were performed on a SCIEX, TripleTOF 5600+, operating in ionization mode.

\subsection{Experimental procedures}

\subsubsection{Procedure for the synthesis of compound 1}

To a solution of 3-bromopropan-1-amine hydrobromide $(3 \mathrm{~g}, 13.7 \mathrm{mmol})$ in anhydrous acetonitrile $(40 \mathrm{~mL})$ was added $\mathrm{KSeCN}(1.97 \mathrm{~g}, 13.7 \mathrm{mmol})$. The mixture was stirred at $80^{\circ} \mathrm{C}$ for 24 hours. Then the mixture was cooled to $25^{\circ} \mathrm{C}$ and filtered. The filter cake was washed with acetonitrile $(5 \mathrm{~mL} \times 2)$ and dried under vacuum to obtain the brown solid 3.1g (Yield =91\%). The isolated solid was used without purification for further reactions.

\subsubsection{General procedure for the synthesis of compounds $(\mathbf{2 a - 2 j})$}

To a solution of patent NSAIDs (1.0 eq) in DCM (5 mL) and DMF (5 mL) was added EDCI (1.2 eq.), HOBT (1.2 eq.) and TEA (3.0 eq.). The mixture was stirred at $25^{\circ} \mathrm{C}$ for 30 minutes. Then 2-selenocyanatoethanamine hydrobromide (1.2 eq) or 2-selenocyanatopropanamine hydrobromide (1.2 eq.) was added into the mixture. The mixture was stirred at $25^{\circ} \mathrm{C}$ for $16 \mathrm{hrs}$. TLC showed the reaction was complete. The 
1 mixture was diluted with $\mathrm{H}_{2} \mathrm{O}(20 \mathrm{~mL})$, the aqueous layer was extracted with DCM

$2(15 \mathrm{~mL} \times 2)$, the combined organic layer was washed with brine $(20 \mathrm{~mL} \times 2)$, dried over

$3 \mathrm{Na}_{2} \mathrm{SO}_{4}$, filtered and the filtrate was concentrated under reduced pressure. The residue

4 was purified by column chromatography on silica gel, eluting with dichloromethane

5 /methanol solution to obtain the desire compound. Yield: $78 \%$. White solid. Mp: 103-105 ${ }^{\circ} \mathrm{C} .{ }^{1} \mathrm{H}$ NMR (400 MHz, $\left.\mathrm{CDCl}_{3}\right): \delta 1.54(\mathrm{~d}, 3 \mathrm{H}$, $\left.J=8.00 \mathrm{~Hz},-\mathrm{CH}_{3}\right), 2.20-2.23\left(\mathrm{~m}, 2 \mathrm{H},-\mathrm{CH}_{2}\right), 2.94-2.99\left(\mathrm{~m}, 2 \mathrm{H},-\mathrm{CH}_{2}\right), 3.76(\mathrm{q}, 1 \mathrm{H}, J$ $10=8.00 \mathrm{~Hz},-\mathrm{CH}), 4.23-4.24\left(\mathrm{~m}, 2 \mathrm{H},-\mathrm{CH}_{2}\right), 7.09-7.15(\mathrm{~m}, 2 \mathrm{H}, \mathrm{ArH}), 7.37-7.43(\mathrm{~m}, 4 \mathrm{H}$, $\mathrm{ArH})$, 7.46-7.54 (m, 2H, ArH). ${ }^{13} \mathrm{C} \mathrm{NMR}\left(100 \mathrm{MHz}, \mathrm{CDCl}_{3}\right): \delta$ 18.2, 25.7, 29.8, 45.0, 63.0, 101.1, $115.2(\mathrm{~d}, J=23.0 \mathrm{~Hz}), 123.5(\mathrm{~d}, J=3.0 \mathrm{~Hz}), 127.8,127.9(\mathrm{~d}, J=14.0 \mathrm{~Hz})$, 129.0, $128.9(\mathrm{~d}, J=2.0 \mathrm{~Hz}), 130.9(\mathrm{~d}, J=4.0 \mathrm{~Hz}), 135.3(\mathrm{~d}, J=2.0 \mathrm{~Hz}), 141.4(\mathrm{~d}, J=$ 7.0Hz), $159.5(\mathrm{~d}, J=247.0 \mathrm{~Hz}), 173.8$. HRMS calcd. For $\mathrm{C}_{19} \mathrm{H}_{18} \mathrm{FNO}_{2} \mathrm{Se}[\mathrm{M}+\mathrm{Na}]^{+}$: 414.0385, found $414.0365[\mathrm{M}+\mathrm{Na}]^{+}$.

16

4.2.2.2. 3-selenocyanatopropyl 2-(4-isobutylphenyl)propanoate (2b). Yield: $82 \%$. White solid. Mp: $97-99^{\circ} \mathrm{C} .{ }^{1} \mathrm{H}$ NMR $\left(400 \mathrm{MHz}, \mathrm{CDCl}_{3}\right): \delta 0.89(\mathrm{~d}, 6 \mathrm{H}, J=8.00 \mathrm{~Hz}$, 2- $\left.\mathrm{CH}_{3}\right), 1.49\left(\mathrm{~d}, 3 \mathrm{H}, J=8.00 \mathrm{~Hz},-\mathrm{CH}_{3}\right), 1.84(\mathrm{q}, 1 \mathrm{H}, J=8.00 \mathrm{~Hz},-\mathrm{CH}), 2.14-2.17(\mathrm{~m}$, $\left.2 \mathrm{H},-\mathrm{CH}_{2}\right), 2.45\left(\mathrm{~d}, 2 \mathrm{H}, J=8.00 \mathrm{~Hz},-\mathrm{CH}_{2}\right), 2.78-2.88\left(\mathrm{~m}, 2 \mathrm{H},-\mathrm{CH}_{2}\right), 3.69(\mathrm{q}, 1 \mathrm{H}, J=$ $8.00 \mathrm{~Hz},-\mathrm{CH}), 4.12-4.27\left(\mathrm{~m}, 2 \mathrm{H},-\mathrm{CH}_{2}\right), 7.10$ (d, 2H, $\left.\mathrm{ArH}\right), 7.18$ (d, 2H, ArH). ${ }^{13} \mathrm{C}$ NMR (100 MHz, $\left.\mathrm{CDCl}_{3}\right): \delta 18.1,22.4,25.7,29.7,30.2,45.0,45.1,62.5,127.1,129.5$, 137.6, 140.9, 174.6. HRMS calcd. For $\mathrm{C}_{17} \mathrm{H}_{23} \mathrm{NO}_{2} \mathrm{Se}[\mathrm{M}+\mathrm{Na}]^{+}$: 376.0792, found $376.0770[\mathrm{M}+\mathrm{Na}]^{+}$.

4.2.2.3.3-selenocyanatopropyl2-(1-(4-chlorobenzoyl)-5-methoxy-2-methyl-1H-indol-3 -yl)acetate (2c). Yield: $78 \%$. White solid. Mp: 110-112 ${ }^{\circ} \mathrm{C} .{ }^{1} \mathrm{H}$ NMR (400 MHz, $\left.\mathrm{CDCl}_{3}\right): \delta 2.19-2.25\left(\mathrm{~m}, 2 \mathrm{H},-\mathrm{CH}_{2}\right), 2.40\left(\mathrm{~s}, 3 \mathrm{H},-\mathrm{CH}_{3}\right), 2.92-3.00\left(\mathrm{~m}, 2 \mathrm{H},-\mathrm{CH}_{2}\right), 3.69$ (s, $\left.2 \mathrm{H},-\mathrm{CH}_{2}\right), 3.84\left(\mathrm{~s}, 3 \mathrm{H},-\mathrm{CH}_{3}\right), 4.24-4.26\left(\mathrm{~m}, 2 \mathrm{H},-\mathrm{CH}_{2}\right), 6.66(\mathrm{~d}, 1 \mathrm{H}, J=4.00 \mathrm{~Hz}$, ArH), 6.86(d, $1 \mathrm{H}, J=8.00 \mathrm{~Hz}, \operatorname{ArH}), 6.93(\mathrm{~s}, 1 \mathrm{H}, \operatorname{ArH}), 7.48(\mathrm{~d}, 2 \mathrm{H}, J=8.00 \mathrm{~Hz}$, 
$1 \mathrm{ArH}), 7.66(\mathrm{~d}, 2 \mathrm{H}, J=8.00 \mathrm{~Hz}, \mathrm{ArH}) .{ }^{13} \mathrm{C} \mathrm{NMR}\left(100 \mathrm{MHz}, \mathrm{CDCl}_{3}\right): 13.4,25.8,29.7$,

$2 \quad 30.4,55.8,63.1,101.2,101.4,111.5,112.2,115.1,129.2,130.5,130.8,131.2,133.7$,

3 136.1, 139.4, 156.0, 168.3, 170.7. HRMS calcd. For $\mathrm{C}_{23} \mathrm{H}_{21} \mathrm{ClN}_{2} \mathrm{O}_{4} \mathrm{Se}[\mathrm{M}+\mathrm{H}]^{+}$:

4505.0433 , found $505.0400[\mathrm{M}+\mathrm{H}]^{+}$.

5

\subsubsection{3-selenocyanatopropyl 2-((2,3-dimethylphenyl)amino)benzoate}

(2d). Yield: $80 \%$. White solid. Mp: 90-92 ${ }^{\circ} \mathrm{C} .{ }^{1} \mathrm{H}$ NMR (400 MHz, $\mathrm{CDCl}_{3}$ ): $\delta 2.17$ (s, $\left.3 \mathrm{H},-\mathrm{CH}_{3}\right), 2.33\left(\mathrm{~s}, 3 \mathrm{H},-\mathrm{CH}_{3}\right), 2.40-2.43\left(\mathrm{~m}, 2 \mathrm{H},-\mathrm{CH}_{2}\right), 3.21-3.24\left(\mathrm{~m}, 2 \mathrm{H},-\mathrm{CH}_{2}\right)$, 4.46-4.49 (m, 2H, $\left.-\mathrm{CH}_{2}\right), 6.66(\mathrm{t}, 1 \mathrm{H}, J=8.00 \mathrm{~Hz}, \mathrm{ArH}), 6.74(\mathrm{~d}, 1 \mathrm{H}, J=8.00 \mathrm{~Hz}$, $\operatorname{ArH}), 7.03(\mathrm{~d}, 1 \mathrm{H}, J=8.00 \mathrm{~Hz}, \operatorname{ArH}), 7.11-7.15(\mathrm{~m}, 2 \mathrm{H}, \operatorname{ArH}), 7.26-7.27(\mathrm{~m}, 1 \mathrm{H}$, $\operatorname{ArH}), 7.91(\mathrm{~d}, 1 \mathrm{H}, J=8.00 \mathrm{~Hz}, \operatorname{ArH}), 9.20(\mathrm{~s}, 1 \mathrm{H},-\mathrm{NH}) .{ }^{13} \mathrm{C}$ NMR $(100 \mathrm{MHz}$, $\left.\mathrm{CDCl}_{3}\right): \delta 14.0,20.6,26.1,30.1,62.5,101.2,110.1,113.8,116.1,123.2,126.0,127.0$, 131.3, 132.6, 134.5, 138.3, 138.5, 149.8, 168.4. HRMS calcd. For $\mathrm{C}_{19} \mathrm{H}_{20} \mathrm{~N}_{2} \mathrm{O}_{2} \mathrm{Se}[\mathrm{M}+\mathrm{H}]^{+}: 389.0768$, found $389.0761[\mathrm{M}+\mathrm{H}]^{+}$.

4.2.2.5. 3-selenocyanatopropyl 2-(1,8-diethyl-1,3,4,9-tetrahydropyrano[3,4-b]indol-1-yl)acetate

(2e). Yield: $85 \%$. White solid. Mp: $130-132{ }^{\circ} \mathrm{C} .{ }^{1} \mathrm{H}$ NMR (400 MHz, $\left.\mathrm{CDCl}_{3}\right): \delta 0.84$ (t, $\left.3 \mathrm{H}, J=8.00 \mathrm{~Hz},-\mathrm{CH}_{3}\right), 1.37\left(\mathrm{t}, 3 \mathrm{H}, J=8.00 \mathrm{~Hz},-\mathrm{CH}_{3}\right), 1.63\left(\mathrm{~s}, 2 \mathrm{H},-\mathrm{CH}_{2}\right)$, 1.94-2.22 (m, 4H, 2- $\left.\mathrm{CH}_{2}\right), 2.71-3.04\left(\mathrm{~m}, 8 \mathrm{H}, 4 \times-\mathrm{CH}_{2}\right), 3.93-4.06\left(\mathrm{~m}, 2 \mathrm{H},-\mathrm{CH}_{2}\right)$, 4.18-4.30 (m, 2H, $\left.-\mathrm{CH}_{2}\right), 7.01-7.09(\mathrm{~m}, 2 \mathrm{H}, \mathrm{ArH}), 7.36(\mathrm{~d}, 1 \mathrm{H}, J=8.00 \mathrm{~Hz}, \operatorname{ArH})$, $8.78(\mathrm{~s}, 1 \mathrm{H},-\mathrm{NH}) .{ }^{13} \mathrm{C} \mathrm{NMR}\left(100 \mathrm{MHz}, \mathrm{CDCl}_{3}\right): \delta$ 7.7, 13.8, 22.3, 24.2, 25.6, 29.7, 31.0, 43.1, 60.7, 63.0, 74.7, 101.2, 108.7, 116.0, 119.8, 120.6, 126.2, 126.6, 134.5, 135.5, 172.3. HRMS calcd. For $\mathrm{C}_{21} \mathrm{H}_{26} \mathrm{~N}_{2} \mathrm{O}_{3} \mathrm{Se}[\mathrm{M}+\mathrm{H}]^{+}$: 435.1187, found 435.1165 $[\mathrm{M}+\mathrm{H}]^{+}$.

\subsubsection{3-selenocyanatopropyl 2-(6-methoxynaphthalen-2-yl)propanoate}

(2f). Yield: $78 \%$. White solid. Mp: $88-90{ }^{\circ} \mathrm{C} .{ }^{1} \mathrm{H}$ NMR $\left(400 \mathrm{MHz}, \mathrm{CDCl}_{3}\right): \delta 1.58$ (d, $\left.3 \mathrm{H}, \mathrm{J}=8.00 \mathrm{~Hz},-\mathrm{CH}_{3}\right), 2.11-2.18\left(\mathrm{~m}, 2 \mathrm{H},-\mathrm{CH}_{2}\right), 2.76-2.90\left(\mathrm{~m}, 2 \mathrm{H},-\mathrm{CH}_{2}\right), 3.83-3.88$ $\left(\mathrm{m}, 2 \mathrm{H},-\mathrm{CH}_{2}\right), 3.92\left(\mathrm{~s}, 3 \mathrm{H},-\mathrm{OCH}_{3}\right), 4.15-4.26(\mathrm{~m}, 1 \mathrm{H},-\mathrm{CH}), 7.15(\mathrm{t}, 1 \mathrm{H}, \mathrm{J}=8.00 \mathrm{~Hz}$, ArH), 7.37 (d, 1H, J = 8.00Hz, ArH), 7.65 (s, 1H, ArH), 7.71(d, 2H, J = 8.00Hz, ArH). 
${ }^{13} \mathrm{C} \mathrm{NMR}\left(100 \mathrm{MHz}, \mathrm{CDCl}_{3}\right): \delta 18.2,25.7,29.7,45.2,55.4,62.7,101.3,105.6,119.3$, 126.0, 126.1, 127.3, 128.9, 129.2, 133.7, 135.4, 157.8, 174.5. HRMS calcd. For $\mathrm{C}_{18} \mathrm{H}_{19} \mathrm{NO}_{3} \mathrm{Se}[\mathrm{M}+\mathrm{H}]^{+}: 378.0608$, found $378.0596[\mathrm{M}+\mathrm{H}]^{+}$.

\subsubsection{3-selenocyanatopropyl 2-((3-(trifluoromethyl)phenyl)amino)benzoate}

(2g). Yield: $77 \%$. White solid. Mp: $121-123^{\circ} \mathrm{C} .{ }^{1} \mathrm{H}$ NMR $\left(400 \mathrm{MHz}, \mathrm{CDCl}_{3}\right): \delta$ 2.38-2.45 (m, 2H, $\left.-\mathrm{CH}_{2}\right), 3.19-3.23\left(\mathrm{~m}, 2 \mathrm{H},-\mathrm{CH}_{2}\right), 4.46-4.49\left(\mathrm{~m}, 2 \mathrm{H},-\mathrm{CH}_{2}\right), 6.82(\mathrm{t}$, $1 \mathrm{H}, J=8.00 \mathrm{~Hz}, \mathrm{ArH}), 7.28-7.49(\mathrm{~m}, 6 \mathrm{H}, \mathrm{ArH}), 7.96(\mathrm{~d}, 1 \mathrm{H}, J=1.0 \mathrm{~Hz}, \mathrm{ArH}), 9.54(\mathrm{~s}$, 1H, -NH). ${ }^{13} \mathrm{C} \mathrm{NMR}\left(100 \mathrm{MHz}, \mathrm{CDCl}_{3}\right): \delta 26.0,30.1,62.9,101.1,112.3,114.3,118.2$ $(\mathrm{q}, J=4.0 \mathrm{~Hz}), 118.3,119.8(\mathrm{q}, J=4.0 \mathrm{~Hz}), 123.9(\mathrm{q}, J=271.0 \mathrm{~Hz}), 124.9,130.0$, 131.6, $131.9(\mathrm{q}, J=32.0 \mathrm{~Hz}), 134.7,141.4,147.1,168.1$. HRMS calcd. For $\mathrm{C}_{18} \mathrm{H}_{15} \mathrm{~F}_{3} \mathrm{~N}_{2} \mathrm{O}_{2} \mathrm{Se}[\mathrm{M}+\mathrm{H}]^{+}$: 429.0329, found $429.0318[\mathrm{M}+\mathrm{H}]^{+}$.

4.2.2.8. 3-selenocyanatopropyl (Z)-2-(5-fluoro-2-methyl-1-(4-(methylsulfinyl)benzylidene)-1H-inden-3-yl)acetate (2h). Yield: 82\%. White solid. Mp: 91-93 ${ }^{\circ} \mathrm{C} .{ }^{1} \mathrm{H}$ NMR (400 $\left.\mathrm{MHz}, \mathrm{CDCl}_{3}\right)$ : $\delta$ 2.21-2.26 (m, 2H, $\left.-\mathrm{CH}_{2}\right), 2.22\left(\mathrm{~s}, 3 \mathrm{H},-\mathrm{CH}_{3}\right), 2.82\left(\mathrm{~s}, 3 \mathrm{H},-\mathrm{CH}_{3}\right), 3.00(\mathrm{t}, 2 \mathrm{H}, J=8.00$ $\left.\mathrm{Hz},-\mathrm{CH}_{2}\right), 4.26\left(\mathrm{t}, 2 \mathrm{H}, J=8.00 \mathrm{~Hz},-\mathrm{CH}_{2}\right), 6.56-6.61(\mathrm{~m}, 1 \mathrm{H}, \mathrm{ArH}), 6.87(\mathrm{~d}, 1 \mathrm{H}, J=$ 8.00 Hz, ArH), 7.15-7.18 (m, 2H, ArH), 7.67(d, 2H, $J=8.00 \mathrm{~Hz}, \mathrm{ArH}), 7.72$ (d, 2H, $J$ $=8.00 \mathrm{~Hz}, \mathrm{ArH}) .{ }^{13} \mathrm{C} \mathrm{NMR}\left(100 \mathrm{MHz}, \mathrm{CDCl}_{3}\right): \delta 10.7,25.7,29.7,31.8,43.9,63.2$, $101.2,105.9(\mathrm{~d}, J=24 \mathrm{~Hz}), 110.9(\mathrm{~d}, J=23 \mathrm{~Hz}), 123.8,123.9,128.6(\mathrm{~d}, J=2.0 \mathrm{~Hz})$, $129.5(\mathrm{~d}, J=3.0 \mathrm{~Hz}), 130.3,131.4(\mathrm{~d}, J=3.0 \mathrm{~Hz}), 138.4,139.5,141.5,145.5,146.5$ $(\mathrm{d}, J=9.0 \mathrm{~Hz}), 163.3(\mathrm{~d}, \quad J=245.0 \mathrm{~Hz})$, 170.1. HRMS calcd. For $\mathrm{C}_{24} \mathrm{H}_{22} \mathrm{FNO}_{3} \mathrm{SSe}[\mathrm{M}+\mathrm{H}]^{+}:$504.0548, found $504.0528[\mathrm{M}+\mathrm{H}]^{+}$.

\subsubsection{3-selenocyanatopropyl 2-(3-benzoylphenyl)propanoate}

(2i). Yield: $85 \%$. White solid. Mp: 96-98 ${ }^{\circ} \mathrm{C} .{ }^{1} \mathrm{H}$ NMR (400 MHz, $\mathrm{CDCl}_{3}$ ): $\delta 1.55$ (d, $\left.3 \mathrm{H}, J=8.00 \mathrm{~Hz},-\mathrm{CH}_{3}\right), 2.18-2.21\left(\mathrm{~m}, 2 \mathrm{H},-\mathrm{CH}_{2}\right), 2.94-2.98\left(\mathrm{~m}, 2 \mathrm{H},-\mathrm{CH}_{2}\right), 3.82(\mathrm{q}$, $1 \mathrm{H}, J=8.00 \mathrm{~Hz},-\mathrm{CH}), 4.21-4.25\left(\mathrm{~m}, 2 \mathrm{H},-\mathrm{CH}_{2}\right), 7.43-7.54(\mathrm{~m}, 4 \mathrm{H}, \mathrm{ArH}), 7.61(\mathrm{t}, 1 \mathrm{H}, J$ $=8.00 \mathrm{~Hz}, \operatorname{ArH}), 7.67(\mathrm{~d}, 1 \mathrm{H}, J=8.00 \mathrm{~Hz}, \mathrm{ArH}), 7.76(\mathrm{~s}, 1 \mathrm{H}, \mathrm{ArH}), 7.80(\mathrm{~d}, 2 \mathrm{H}, J=$ $8.00 \mathrm{~Hz}, \mathrm{ArH}) .{ }^{13} \mathrm{C} \mathrm{NMR}\left(100 \mathrm{MHz}, \mathrm{CDCl}_{3}\right): \delta 18.3,25.7,29.7,45.4,63.0,101.2$, 
$1 \quad 128.4,128.6,129.0,129.2,130.1,131.4,132.7,137.4,138.1,140.7,173.8,196.4$.

$2 \quad$ HRMS calcd. For $\mathrm{C}_{20} \mathrm{H}_{19} \mathrm{NO}_{3} \mathrm{Se}[\mathrm{M}+\mathrm{H}]^{+}:$402.0608, found $402.0588[\mathrm{M}+\mathrm{H}]^{+}$.

3

4.2.2.10. 3-selenocyanatopropyl 2-acetoxybenzoate (2j). Yield: 90\%. White solid. Mp: 117-118 ${ }^{\circ} \mathrm{C} .{ }^{1} \mathrm{H}$ NMR $\left(400 \mathrm{MHz}, \mathrm{CDCl}_{3}\right): \delta 2.38\left(\mathrm{~s}, 3 \mathrm{H},-\mathrm{CH}_{3}\right), 2.33-2.40(\mathrm{~m}, 2 \mathrm{H}$, $\left.-\mathrm{CH}_{2}\right), 3.11-3.17\left(\mathrm{~m}, 2 \mathrm{H},-\mathrm{CH}_{2}\right), 4.44-4.46\left(\mathrm{~m}, 2 \mathrm{H},-\mathrm{CH}_{2}\right), 7.12(\mathrm{~d}, 1 \mathrm{H}, J=8.00 \mathrm{~Hz}$, ArH), $7.33(\mathrm{t}, 1 \mathrm{H}, J=8.00 \mathrm{~Hz}, \operatorname{ArH}), 7.58(\mathrm{t}, 1 \mathrm{H}, J=8.00 \mathrm{~Hz}, \operatorname{ArH}), 7.99(\mathrm{~d}, 1 \mathrm{H}, \mathrm{J}=$ 8.00Hz, ArH). ${ }^{13} \mathrm{C}$ NMR $\left(100 \mathrm{MHz}, \mathrm{CDCl}_{3}\right): \delta 21.1,25.8,30.0,63.1,101.3,122.8$, 123.9, 126.1, 131.5, 134.3, 150.7, 164.3, 169.8. HRMS calcd. For $\mathrm{C}_{24} \mathrm{H}_{23} \mathrm{FN}_{2} \mathrm{O}_{2} \mathrm{SSe}[\mathrm{M}+\mathrm{Na}]^{+}: 349.9908$, found $349.9896[\mathrm{M}+\mathrm{Na}]^{+}$.

\subsubsection{General procedure for the synthesis of compounds $\mathbf{3 a - 3 j}$}

To a solution of compound $\mathbf{2} \mathbf{a}-\mathbf{2} \mathbf{j}$ (300 $\mathrm{mg}, 1.0$ eq.) in THF (10ml) was added $\operatorname{TBAF}$ (1 eq.) and $\mathrm{TMSCF}_{3}$ (10 eq.). The mixture was stirred at $25^{\circ} \mathrm{C}$ for 2 hours. TLC showed the reaction was completed. The mixture was concentrated under reduced pressure. The desire compound was purified by column chromatography on silica gel.

\subsubsection{3-((trifluoromethyl)selanyl)propyl 2-(2-fluoro-[1,1'-biphenyl]-4-yl)propanoate} (3a). Yield: $80 \%$. White solid. Mp: $113-115^{\circ} \mathrm{C} .{ }^{1} \mathrm{H}$ NMR (400 $\left.\mathrm{MHz}, \mathrm{CDCl}_{3}\right): \delta 1.54$ $\left(\mathrm{d}, 3 \mathrm{H}, J=8.00 \mathrm{~Hz},-\mathrm{CH}_{3}\right), 2.09-2.12\left(\mathrm{~m}, 2 \mathrm{H},-\mathrm{CH}_{2}\right), 2.90-2.93\left(\mathrm{~m}, 2 \mathrm{H},-\mathrm{CH}_{2}\right), 3.75$ (q, $1 \mathrm{H}, J=8.00 \mathrm{~Hz},-\mathrm{CH}), 4.20-4.22\left(\mathrm{~m}, 2 \mathrm{H},-\mathrm{CH}_{2}\right), 7.13(\mathrm{t}, 2 \mathrm{H}, J=8.00 \mathrm{~Hz}, \mathrm{ArH})$, 7.37-7.39 (m, 2H, ArH), 7.44 (t, 2H, $J=8.00 \mathrm{~Hz}, \mathrm{ArH}), 7.53(\mathrm{~d}, 2 \mathrm{H}, J=8.00 \mathrm{~Hz}$, ArH). $\left.{ }^{13} \mathrm{C} \mathrm{NMR} \mathrm{(100} \mathrm{MHz,} \mathrm{CDCl}_{3}\right): \delta 18.2,21.8,29.4,45.0,63.6,115.2(\mathrm{~d}, J=24.0$ $\mathrm{Hz}), 122.5$ (q, $\left.J=329.0 \mathrm{~Hz},-\mathrm{SeCF}_{3}\right), 123.4$ (d, $\left.J=3.0 \mathrm{~Hz}\right), 127.7,128.0(\mathrm{~d}, J=13.0$ Hz), 128.5, 128.9 (d, J = 5.0 Hz), 130.9 (d, $J=4.0 \mathrm{~Hz}), 135.4,141.5$ (d, $J=7.0 \mathrm{~Hz})$, $159.7(\mathrm{~d}, J=247.0 \mathrm{~Hz}), 173.8 .{ }^{19} \mathrm{~F} \mathrm{NMR}\left(\mathrm{CDCl}_{3}, 376 \mathrm{MHz}\right): \delta-34.3\left(\mathrm{~s},-\mathrm{SeCF}_{3}\right)$, -117.5 (s, F). HRMS calcd. For $\mathrm{C}_{19} \mathrm{H}_{18} \mathrm{~F}_{4} \mathrm{O}_{2} \mathrm{Se}[\mathrm{M}+\mathrm{H}]^{+}$: 435.0486, found 435.0462 $[\mathrm{M}+\mathrm{H}]^{+}$. 
2 Yield: $82 \%$. Yellow solid. Mp: $102-104^{\circ} \mathrm{C} .{ }^{1} \mathrm{H}$ NMR $\left(400 \mathrm{MHz}, \mathrm{CDCl}_{3}\right): \delta 0.89$ (d, $\left.36 \mathrm{H}, J=8.00 \mathrm{~Hz}, 2-\mathrm{CH}_{3}\right), 1.49\left(\mathrm{~d}, 3 \mathrm{H}, J=8.00 \mathrm{~Hz},-\mathrm{CH}_{3}\right), 1.84(\mathrm{q}, 1 \mathrm{H}, J=8.00 \mathrm{~Hz}$, $-\mathrm{CH}), 2.04-2.07\left(\mathrm{~m}, 2 \mathrm{H},-\mathrm{CH}_{2}\right), 2.44\left(\mathrm{~d}, 2 \mathrm{H}, J=8.00 \mathrm{~Hz},-\mathrm{CH}_{2}\right), 2.78-2.83(\mathrm{~m}, 2 \mathrm{H}$, $\left.-\mathrm{CH}_{2}\right), 3.68(\mathrm{q}, 1 \mathrm{H}, J=8.00 \mathrm{~Hz},-\mathrm{CH}), 4.12-4.21\left(\mathrm{~m}, 2 \mathrm{H},-\mathrm{CH}_{2}\right), 7.09(\mathrm{~d}, 2 \mathrm{H}, \mathrm{ArH})$, $7.18(\mathrm{~d}, 2 \mathrm{H}, \mathrm{ArH}) .{ }^{13} \mathrm{C} \mathrm{NMR}\left(100 \mathrm{MHz}, \mathrm{CDCl}_{3}\right): \delta 18.2,21.8,22.4,29.4,30.2,45.0$, $45.1,63.1,122.5\left(\mathrm{q}, J=328.0 \mathrm{~Hz},-\mathrm{SeCF}_{3}\right), 127.1,129.4,137.6,140.7,174.6 .{ }^{19} \mathrm{~F}$ NMR $\left(\mathrm{CDCl}_{3}, 376 \mathrm{MHz}\right): \delta-34.3\left(\mathrm{~s},-\mathrm{SeCF}_{3}\right)$. HRMS calcd. For $\mathrm{C}_{17} \mathrm{H}_{23} \mathrm{~F}_{3} \mathrm{O}_{2} \mathrm{Se}$ $[\mathrm{M}+\mathrm{H}]^{+}:$397.0893, found $397.0883[\mathrm{M}+\mathrm{H}]^{+}$.

4.2.3.3. 3-((trifluoromethyl)selanyl)propyl 2-(1-(4-chlorobenzoyl)-5-methoxy-2-methyl-1H-indol-3-yl)acetate (3c). Yield: 80\%. White solid. Mp: $131-133^{\circ} \mathrm{C} .{ }^{1} \mathrm{H}$ NMR (400 MHz, $\left.\mathrm{CDCl}_{3}\right): \delta 2.09-2.15\left(\mathrm{~m}, 2 \mathrm{H},-\mathrm{CH}_{2}\right.$ ), $2.40\left(\mathrm{~s}, 3 \mathrm{H},-\mathrm{CH}_{3}\right), 2.91-2.95\left(\mathrm{~m}, 2 \mathrm{H},-\mathrm{CH}_{2}\right), 3.68\left(\mathrm{~s}, 2 \mathrm{H},-\mathrm{CH}_{2}\right), 3.84\left(\mathrm{~s}, 3 \mathrm{H},-\mathrm{CH}_{3}\right)$, 4.20-4.23 (m, 2H, $\left.-\mathrm{CH}_{2}\right), 6.67$ (d, $\left.1 \mathrm{H}, J=4.00 \mathrm{~Hz}, \mathrm{ArH}\right), 6.85(\mathrm{~d}, 1 \mathrm{H}, J=8.00 \mathrm{~Hz}$, $\operatorname{ArH}), 6.94(\mathrm{~s}, 1 \mathrm{H}, \operatorname{ArH}), 7.48(\mathrm{~d}, 2 \mathrm{H}, J=8.00 \mathrm{~Hz}, \operatorname{ArH}), 7.66(\mathrm{~d}, 2 \mathrm{H}, J=8.00 \mathrm{~Hz}$, ArH). ${ }^{13} \mathrm{C} \mathrm{NMR}\left(100 \mathrm{MHz}, \mathrm{CDCl}_{3}\right): \delta 13.3,21.9,29.4,30.3,55.7,63.7,101.3,111.6$, 112.3, 115.0, 122.5 (q, $\left.J=329 \mathrm{~Hz},-\mathrm{SeCF}_{3}\right), 129.2,130.5,130.8,131.2,133.9,136.0$, 139.3, 156.1, 168.3, 170.7. ${ }^{19} \mathrm{~F} \mathrm{NMR}\left(\mathrm{CDCl}_{3}, 376 \mathrm{MHz}\right): \delta-34.3\left(\mathrm{~s},-\mathrm{SeCF}_{3}\right) . \mathrm{HRMS}$ calcd. For $\mathrm{C}_{23} \mathrm{H}_{21} \mathrm{ClF}_{3} \mathrm{NO}_{4} \mathrm{Se}[\mathrm{M}+\mathrm{H}]^{+}:$548.0354, found 508.0305 $[\mathrm{M}+\mathrm{H}]^{+}$.

\subsubsection{3-((trifluoromethyl)selanyl)propyl 2-((2,3-dimethylphenyl)amino)benzoate} (3d). Yield: $82 \%$. White solid. Mp: $116-118^{\circ} \mathrm{C} .{ }^{1} \mathrm{H}$ NMR (400 MHz, $\mathrm{CDCl}_{3}$ ): $\delta 2.18$ (s, 3H, $\left.-\mathrm{CH}_{3}\right), 2.28-2.31\left(\mathrm{~m}, 2 \mathrm{H},-\mathrm{CH}_{2}\right), 2.33\left(\mathrm{~s}, 3 \mathrm{H},-\mathrm{CH}_{3}\right), 3.13-3.17\left(\mathrm{~m}, 2 \mathrm{H},-\mathrm{CH}_{2}\right)$, 4.41-4.44 (m, 2H, - $\left.\mathrm{CH}_{2}\right), 6.67$ (t, $\left.1 \mathrm{H}, J=8.00 \mathrm{~Hz}, \mathrm{ArH}\right), 6.75(\mathrm{~d}, 1 \mathrm{H}, J=8.00 \mathrm{~Hz}$, $\operatorname{ArH}), 7.02(\mathrm{~d}, 1 \mathrm{H}, J=8.00 \mathrm{~Hz}, \operatorname{ArH}), 7.10-7.15(\mathrm{~m}, 2 \mathrm{H}, \operatorname{ArH}), 7.23-7.27(\mathrm{~m}, 1 \mathrm{H}$, ArH), $7.93(\mathrm{~d}, 1 \mathrm{H}, J=8.00 \mathrm{~Hz}, \operatorname{ArH}), 9.23(\mathrm{~s}, 1 \mathrm{H},-\mathrm{NH}) .{ }^{13} \mathrm{C} \mathrm{NMR}(100 \mathrm{MHz}$, $\left.\mathrm{CDCl}_{3}\right): \delta 14.0,20.7,22.2,29.7,63.1,110.4,113.8,116.1,122.6(\mathrm{q}, J=328.0 \mathrm{~Hz}$, $\left.-\mathrm{SeCF}_{3}\right), 123.2,126.0,126.9,131.3,132.5,134.4,138.3,138.6,149.7,168.5 .{ }^{19} \mathrm{~F}$ 
$1 \quad \mathrm{NMR}\left(\mathrm{CDCl}_{3}, 376 \mathrm{MHz}\right): \delta$-34.2 (s, $\left.-\mathrm{SeCF}_{3}\right)$. HRMS calcd. For $\mathrm{C}_{19} \mathrm{H}_{20} \mathrm{~F}_{3} \mathrm{NO}_{2} \mathrm{Se}$ $2 \quad[\mathrm{M}+\mathrm{H}]^{+}:$432.0611, found $432.0675[\mathrm{M}+\mathrm{H}]^{+}$.

3

$4 \quad$ 4.2.3.5. 3-((trifluoromethyl)selanyl)propyl

2-(1,8-diethyl-1,3,4,9-tetrahydropyrano[3,4-b]indol-1-yl)acetate (3e). Yield: $82 \%$. White solid. Mp: $127-129^{\circ} \mathrm{C} .{ }^{1} \mathrm{H} \mathrm{NMR}\left(400 \mathrm{MHz}, \mathrm{CDCl}_{3}\right): \delta 0.84$ (t, 3H, J=8.00 Hz, $\left.-\mathrm{CH}_{3}\right), 1.37\left(\mathrm{t}, 3 \mathrm{H}, J=8.00 \mathrm{~Hz},-\mathrm{CH}_{3}\right), 1.99-2.16\left(\mathrm{~m}, 4 \mathrm{H}, 2 \times-\mathrm{CH}_{2}\right), 2.75-3.04(\mathrm{~m}, 8 \mathrm{H}$, 4- $\mathrm{CH}_{2}$ ), 3.93-4.06 (m, 2H, $-\mathrm{CH}_{2}$ ), 4.18-4.30 (m, 2H, $\left.-\mathrm{CH}_{2}\right), 7.01-7.07$ (m, 2H, ArH), $7.36(\mathrm{~d}, 1 \mathrm{H}, J=8.00 \mathrm{~Hz}, \mathrm{ArH}), 8.94(\mathrm{~s}, 1 \mathrm{H},-\mathrm{NH}) .{ }^{13} \mathrm{C} \mathrm{NMR}\left(100 \mathrm{MHz}, \mathrm{CDCl}_{3}\right): \delta$ $7.6,13.8,21.9,22.4,24.2,29.3,30.8,43.0,60.7,63.6,74.6,108.6,116.0,119.7$, $120.5,122.5$ (q, J = $\left.329 \mathrm{~Hz},-\mathrm{SeCF}_{3}\right), 126.2,126.6,134.5,135.7,172.6 .{ }^{19} \mathrm{~F} \mathrm{NMR}$ $\left(\mathrm{CDCl}_{3}, 376 \mathrm{MHz}\right): \delta-34.2\left(\mathrm{~s},-\mathrm{SeCF}_{3}\right)$. HRMS calcd. For $\mathrm{C}_{21} \mathrm{H}_{26} \mathrm{~F}_{3} \mathrm{NO}_{3} \mathrm{Se}[\mathrm{M}+\mathrm{H}]^{+}$: 478.1108, found $478.1089[\mathrm{M}+\mathrm{H}]^{+}$.

4.2.3.6. 3-((trifluoromethyl)selanyl)propyl 2-(6-methoxynaphthalen-2-yl)propanoate (3f). Yield: $85 \%$. White solid. Mp: $125-127^{\circ} \mathrm{C} .{ }^{1} \mathrm{H}$ NMR (400 MHz, $\left.\mathrm{CDCl}_{3}\right): \delta 1.58(\mathrm{~d}$, $\left.3 \mathrm{H}, J=8.00 \mathrm{~Hz},-\mathrm{CH}_{3}\right), 2.03-2.07\left(\mathrm{~m}, 2 \mathrm{H},-\mathrm{CH}_{2}\right), 2.82-2.86\left(\mathrm{~m}, 2 \mathrm{H},-\mathrm{CH}_{2}\right), 3.87(\mathrm{q}$, $1 \mathrm{H}, J=8.00 \mathrm{~Hz},-\mathrm{CH}), 3.91\left(\mathrm{~s}, 3 \mathrm{H},-\mathrm{OCH}_{3}\right), 4.16-4.19\left(\mathrm{~m}, 2 \mathrm{H},-\mathrm{CH}_{2}\right), 7.12(\mathrm{t}, 1 \mathrm{H}, J=$ $8.00 \mathrm{~Hz}, \operatorname{ArH}), 7.38(\mathrm{~d}, 1 \mathrm{H}, J=8.00 \mathrm{~Hz}, \operatorname{ArH}), 7.65(\mathrm{~s}, 1 \mathrm{H}, \operatorname{ArH}), 7.70(\mathrm{~d}, 2 \mathrm{H}, J=$ 8.00Hz, ArH). ${ }^{13} \mathrm{C} \mathrm{NMR}\left(100 \mathrm{MHz}, \mathrm{CDCl}_{3}\right): \delta 18.3,21.8,29.4,45.4,55.3,63.3$, 105.6, 119.1, 122.5 (d, $\left.J=328.0 \mathrm{~Hz},-\mathrm{SeCF}_{3}\right), 125.9,126.1,127.2,128.9,129.3$, 133.7, 135.5, 157.7, 174.6. ${ }^{19} \mathrm{~F} \mathrm{NMR}\left(\mathrm{CDCl}_{3}, 376 \mathrm{MHz}\right): \delta-34.3\left(\mathrm{~s},-\mathrm{SeCF}_{3}\right) . \mathrm{HRMS}$ calcd. For $\mathrm{C}_{18} \mathrm{H}_{19} \mathrm{~F}_{3} \mathrm{O}_{3} \mathrm{Se}[\mathrm{M}+\mathrm{Na}]^{+}$: 443.0350, found $443.0337[\mathrm{M}+\mathrm{Na}]^{+}$.

4.2.3.7.

3-((trifluoromethyl)selanyl)propyl 2-((3-(trifluoromethyl)phenyl)amino)benzoate (3g). Yield: 80\%. White solid. Mp: 99-101 ${ }^{\circ} \mathrm{C} .{ }^{1} \mathrm{H}$ NMR (400 MHz, $\mathrm{CDCl}_{3}$ ): $\delta$ 2.27-2.33 (m, 2H, $-\mathrm{CH}_{2}$ ), 3.12-3.16 (m, 2H, $\left.-\mathrm{CH}_{2}\right), 4.42-4.45\left(\mathrm{~m}, 2 \mathrm{H},-\mathrm{CH}_{2}\right), 6.83(\mathrm{t}, 1 \mathrm{H}, J=8.00 \mathrm{~Hz}, \mathrm{ArH}), 7.27-7.49(\mathrm{~m}, 6 \mathrm{H}$, $\mathrm{ArH}), 7.97(\mathrm{~d}, 1 \mathrm{H}, J=1.0 \mathrm{~Hz}, \mathrm{ArH}), 9.58(\mathrm{~s}, 1 \mathrm{H},-\mathrm{NH}) .{ }^{13} \mathrm{C} \mathrm{NMR}\left(100 \mathrm{MHz}, \mathrm{CDCl}_{3}\right)$ : $\delta 22.1,29.6,63.5,112.5,114.3,118.2(\mathrm{q}, J=4.0 \mathrm{~Hz}), 118.3,119.7(\mathrm{q}, J=4.0 \mathrm{~Hz})$, 
$1 \quad 122.6\left(\mathrm{q}, J=328.0 \mathrm{~Hz},-\mathrm{SeCF}_{3}\right), 124.0\left(\mathrm{q}, J=270 \mathrm{~Hz},-\mathrm{CF}_{3}\right), 124.7,129.9,131.6$,

$2131.8(\mathrm{q}, J=32.0 \mathrm{~Hz}), 134.5,141.5,147.0,168.2 .{ }^{19} \mathrm{~F} \mathrm{NMR}\left(\mathrm{CDCl}_{3}, 376 \mathrm{MHz}\right): \delta$

$3 \quad-34.2\left(\mathrm{~s},-\mathrm{SeCF}_{3}\right),-62.8\left(\mathrm{~s},-\mathrm{CF}_{3}\right)$. HRMS calcd. For $\mathrm{C}_{18} \mathrm{H}_{15} \mathrm{~F}_{6} \mathrm{NO}_{2} \mathrm{Se}[\mathrm{M}+\mathrm{H}]^{+}$:

$4 \quad 472.0250$, found $472.0233[\mathrm{M}+\mathrm{H}]^{+}$.

5

$6 \quad 4.2 .3 .8$. 3-((trifluoromethyl)selanyl)propyl

(Z)-2-(5-fluoro-2-methyl-1-(4-(methylsulfinyl)benzylidene)-1H-inden-3-yl)acetate

(3h). Yield: $80 \%$. White solid. Mp: $116-118^{\circ} \mathrm{C} .{ }^{1} \mathrm{H}$ NMR $\left(400 \mathrm{MHz}, \mathrm{CDCl}_{3}\right): \delta$ 2.10-2.13 (m, 2H, $\left.-\mathrm{CH}_{2}\right), 2.21\left(\mathrm{~s}, 3 \mathrm{H},-\mathrm{CH}_{3}\right), 2.82\left(\mathrm{~s}, 3 \mathrm{H},-\mathrm{CH}_{3}\right), 2.94(\mathrm{t}, 2 \mathrm{H}, J=8.00$ $\left.\mathrm{Hz},-\mathrm{CH}_{2}\right), 3.58$ (s, 2H, $-\mathrm{CH}_{2}$ ), 4.22 (t, 2H, J=8.00 Hz, $\left.-\mathrm{CH}_{2}\right), 6.55-6.60(\mathrm{~m}, 1 \mathrm{H}, \mathrm{ArH})$, $6.87(\mathrm{~d}, 1 \mathrm{H}, J=8.00 \mathrm{~Hz}, \operatorname{ArH}), 7.14-7.18(\mathrm{~m}, 2 \mathrm{H}, \operatorname{ArH}), 7.67(\mathrm{~d}, 2 \mathrm{H}, J=8.00 \mathrm{~Hz}$, $\operatorname{ArH}), 7.72(\mathrm{~d}, 2 \mathrm{H}, J=8.00 \mathrm{~Hz}, \mathrm{ArH}) .{ }^{13} \mathrm{C} \mathrm{NMR}\left(100 \mathrm{MHz}, \mathrm{CDCl}_{3}\right): \delta 10.5,21.8$, 29.3, 31.8, 43.9, 63.7, 105.9 (d, $J=23 \mathrm{~Hz}), 110.4$ (d, $J=23 \mathrm{~Hz}), 122.5$ (q, $J=328 \mathrm{~Hz}$, $\left.-\mathrm{SeCF}_{3}\right), 123.7(\mathrm{~d}, J=9.0 \mathrm{~Hz}), 123.8,128.4(\mathrm{~d}, J=2.0 \mathrm{~Hz}), 129.5(\mathrm{~d}, J=3.0 \mathrm{~Hz})$, $130.3,131.5(\mathrm{~d}, J=2.0 \mathrm{~Hz}), 138.3,139.6,141.6,145.5,146.5(\mathrm{~d}, J=9.0 \mathrm{~Hz}), 163.3$ (d, $J=245 \mathrm{~Hz}), 170.0 .{ }^{19} \mathrm{~F}$ NMR $\left(\mathrm{CDCl}_{3}, 376 \mathrm{MHz}\right): \delta-34.3\left(\mathrm{~s},-\mathrm{SeCF}_{3}\right),-112.8(\mathrm{~s},-\mathrm{F})$. HRMS calcd. For $\mathrm{C}_{24} \mathrm{H}_{22} \mathrm{~F}_{4} \mathrm{O}_{3} \mathrm{SSe}[\mathrm{M}+\mathrm{Na}]^{+}:$569.0289, found $569.0263[\mathrm{M}+\mathrm{Na}]^{+}$.

4.2.3.9. 3-((trifluoromethyl)selanyl)propyl 2-(3-benzoylphenyl)propanoate (3i). Yield: 85\%. White solid. Mp: 87-89 ${ }^{\circ} \mathrm{C} .{ }^{1} \mathrm{H}$ NMR (400 MHz, $\left.\mathrm{CDCl}_{3}\right): \delta 1.55(\mathrm{~d}, 3 \mathrm{H}, \mathrm{J}=$ $\left.8.00 \mathrm{~Hz},-\mathrm{CH}_{3}\right), 2.05-2.12\left(\mathrm{~m}, 2 \mathrm{H},-\mathrm{CH}_{2}\right), 2.87-2.89\left(\mathrm{~m}, 2 \mathrm{H},-\mathrm{CH}_{2}\right), 3.82(\mathrm{q}, 1 \mathrm{H}, J=$ $8.00 \mathrm{~Hz},-\mathrm{CH}), 4.19-4.21\left(\mathrm{~m}, 2 \mathrm{H},-\mathrm{CH}_{2}\right), 7.43-7.59$ (m, 4H, ArH), 7.60 (t, $1 \mathrm{H}, J=8.00$ $\mathrm{Hz}, \mathrm{ArH}), 7.67$ (d, 1H, J = 8.00 Hz, ArH), 7.76 (s, 1H, ArH), 7.79 (d, 2H, J = 8.00 Hz, ArH). ${ }^{13} \mathrm{C}$ NMR $\left(100 \mathrm{MHz}, \mathrm{CDCl}_{3}\right): \delta 18.3,21.8,29.4,45.4,63.5,122.5$ (q, $J=329.0$ $\left.\mathrm{Hz},-\mathrm{SeCF}_{3}\right), 128.4,128.6,129.1,129.2$, 130.1, 131.4, 132.6, 137.4, 138.0, 140.7, 174.0, 195.5. ${ }^{19} \mathrm{~F}$ NMR $\left(\mathrm{CDCl}_{3}, 376 \mathrm{MHz}\right): \delta-34.2\left(\mathrm{~s},-\mathrm{SeCF}_{3}\right)$. HRMS calcd. For $\mathrm{C}_{20} \mathrm{H}_{19} \mathrm{~F}_{3} \mathrm{O}_{3} \mathrm{Se}[\mathrm{M}+\mathrm{H}]^{+}$: 445.0530, found 445.0491 [M+H] $]^{+}$.

4.2.3.10. 3-((trifluoromethyl)selanyl)propyl 2-acetoxybenzoate (3j). Yield: 80\%. White solid. Mp: $104-106^{\circ} \mathrm{C} .{ }^{1} \mathrm{H}$ NMR $\left(400 \mathrm{MHz}, \mathrm{CDCl}_{3}\right): \delta 2.23-2.28\left(\mathrm{~m}, 2 \mathrm{H},-\mathrm{CH}_{2}\right.$, 
$12.35\left(\mathrm{~s}, 3 \mathrm{H},-\mathrm{CH}_{3}\right), 3.07-3.10\left(\mathrm{~m}, 2 \mathrm{H},-\mathrm{CH}_{2}\right), 4.38-4.41\left(\mathrm{~m}, 2 \mathrm{H},-\mathrm{CH}_{2}\right), 7.11(\mathrm{~d}, 1 \mathrm{H}, J$ $2=8.00 \mathrm{~Hz}, \mathrm{ArH}), 7.30-7.57(\mathrm{~m}, 1 \mathrm{H}, \mathrm{ArH}), 7.58-7.60(\mathrm{~m}, 1 \mathrm{H}, \mathrm{ArH}), 7.99(\mathrm{~d}, 1 \mathrm{H}, J=$ $38.00 \mathrm{~Hz}, \mathrm{ArH}) .{ }^{13} \mathrm{C} \mathrm{NMR}\left(100 \mathrm{MHz}, \mathrm{CDCl}_{3}\right): \delta 21.0,22.0,29.6,63.7,122.6$ (q, $J=$ $\left.4328 \mathrm{~Hz},-\mathrm{SeCF}_{3}\right), 123.0,123.9,131.6,134.1,150.8,164.3,169.7 .{ }^{19} \mathrm{~F} \mathrm{NMR}\left(\mathrm{CDCl}_{3}\right.$, $5376 \mathrm{MHz}): \delta$-34.2 (s, $-\mathrm{SeCF}_{3}$ ). HRMS calcd. For $\mathrm{C}_{13} \mathrm{H}_{13} \mathrm{~F}_{3} \mathrm{O}_{4} \mathrm{Se}[\mathrm{M}+\mathrm{H}]^{+}: 392.9829$, 6 found $392.9827[\mathrm{M}+\mathrm{H}]^{+}$.

4.3. Cell lines and culture conditions

Four human cancer cell lines Caco-2, BGC-823, MCF-7 and PC-3 cells were maintained in RPMI 1640 medium with 10\% fetal bovine serum (FBS) and 100 11 units/mL of penicillin and streptomycin (Thermo Fisher Scientific, shanghai, China) 12 at $37{ }^{\circ} \mathrm{C}$ and $5 \% \mathrm{CO}_{2}$ in a humidified atmosphere. Cells were passaged at 13 preconfluent densities, using a solution containing $0.05 \%$ trypsin and $0.5 \mathrm{mM}$ EDTA. 14 Human cancer cell lines Caco-2, BGC-823, MCF-7 and PC-3 used in this work were obtained from the American Type Culture Collection (ATCC, Manassas, VA).

All the tested NSAIDs-Se derivatives were evaluated in vitro for their antitumor activity against four cancer cell lines by 3-(4,5-dimethylthiazol-2-yl)-2,5-diphenyl-2H-tetrazolium bromide (MTT) assay according to the method as described before [57-58]. Exponentially growing cells were harvested and plated in 96-well plates at a concentration of $1 \times 104$ cells / well. After $24 \mathrm{~h}$ incubation at $37{ }^{\circ} \mathrm{C}$ under a humidified $5 \% \mathrm{CO}_{2}$ to allow cell attachment, the cells in the wells were respectively treated with target compounds at various concentrations for $24 \mathrm{~h}, 48 \mathrm{~h}$ and $72 \mathrm{~h}$. The concentration of DMSO was always kept below $1.25 \%$, which was found to be non-toxic to the cells. Three hours prior to experiment termination, MTT solution $(20 \mu \mathrm{L}$ of $5.0 \mathrm{mg} / \mathrm{mL}$ solution) was added to each well and incubated at $37^{\circ} \mathrm{C}$. At the termination time point, the medium/MTT mixtures were removed, and the formazan crystals formed by the mitochondrial dehydrogenase activity of vital cells were dissolved in $100 \mu \mathrm{L}$ of DMSO per well. The optical densities were measured at $570 \mathrm{~nm}$ using a 96-well multiscanner (Dynex Technologies, MRX Revelation; Chantilly, VA, USA). 


\subsection{Detection of Bcl-2, IL-2 and caspase- 8 protein expression levels}

2

3

corresponding $\mathrm{IC}_{50} \mathrm{~s}$ of each compound and incubated for $48 \mathrm{~h}$ and compared with their levels in control untreated BGC-823 cell line. The cells were harvested by applying trypsin and lysed by freezing with liquid nitrogen and then thawing with gentle mixing and the total proteins were isolated. Protein levels of the anti-apoptotic marker Bcl-2 were then measured using enzymelinked immunosorbent assay (ELISA) according to the manufacturers' instructions (Merck, USA). Enzyme-linked immunosorbent assay was used for quantitative detection of IL-2 and caspase-8 (Platinum ELISA). The reaction product was detected at $450 \mathrm{~nm}$ using enzyme-linked immunosorbent assay (Platinum ELISA; Merck) according to the instructions of the manufacturer.

3

\subsection{DPPH free radical scavenging activity}

DPPH free radical scavenging activity of corresponding compounds was measured according to the method as previous reported with little optimization [59]. Briefly, $20 \mathrm{~mL}$ of test samples at different concentrations was mixed with $180 \mathrm{~mL}$ of or DPPH solution for $30 \mathrm{~min}$ in the dark. Then, the change in absorbance at $517 \mathrm{~nm}$ for DPPH was measured on a microplate reader. Ascorbic acid (vitamin C) and ebselen were used as a positive control, DMSO was used as a negative control.

\subsection{Bleomycin-dependent DNA damage}

The reaction mixture contained DNA $(0.5 \mathrm{mg} / \mathrm{mL})$, bleomycin sulfate $(0.05 \mathrm{mg} / \mathrm{mL}), \mathrm{MgCl}_{2}(5 \mathrm{mM}), \mathrm{FeCl}_{3}(50 \mathrm{mM})$, and tested compound in a conc. of $0.1 \mathrm{mg} / \mathrm{mL}$. L-ascorbic acid was used as positive control. The mixture was incubated at $37^{\circ} \mathrm{C}$ for $1 \mathrm{~h}$. The reaction was terminated by addition of $0.05 \mathrm{~mL}$ EDTA $(0.1 \mathrm{M})$. The color was developed by adding $0.5 \mathrm{~mL}$ TBA $(1 \% \mathrm{w} / \mathrm{v})$ and $0.5 \mathrm{~mL} \mathrm{HCl}(25 \% \mathrm{v} / \mathrm{v})$, followed by heating at $80^{\circ} \mathrm{C}$ for 30 minutes. After cooling in ice water, the extent of DNA damage was measured by increase in absorbance at $532 \mathrm{~nm}$ [60]. 


\subsection{Glutathione peroxidase-like activity}

GPx kit (Biodiagnostic, Egypt) was used for the determination of GPx according to Paglia et al [61]. The reaction mixture contained $1 \mathrm{ml}$ assay buffer $(50 \mathrm{mM}$ phosphate buffer containing $0.1 \%$ Triton X-100) and $0.1 \mathrm{ml}$ NADPH reagent (24 mmol Glutathione, 12 unit Glutathione reductase and $4.8 \mathrm{mmol}$ NADPH) and $0.01 \mathrm{ml}$ (41 mM) tested compounds and the reaction was started by the addition of $\mathrm{H}_{2} \mathrm{O}_{2}(0.8$ $\mathrm{mM})$. The contents were mixed well and the absorbances were recorded at $340 \mathrm{~nm}$ over a period of $3 \mathrm{~min}$ against deionized water. The change of absorbance per minute (A340 $\mathrm{nm} / \mathrm{min}$ ) was estimated using ebselen $(41 \mathrm{mM})$ as positive control. The values represented in Fig 3 are expressed after background correction for the reaction with $\mathrm{H}_{2} \mathrm{O}_{2}$ and GSH. In case of colored compounds, their activities were estimated after subtracting their own absorbances at the used wave length.

\subsection{Molecular Modeling}

\subsubsection{Protein and Ligand Preparation}

Prepared by Protein Preparation Wizard in Maestro 11.5 (Schrödinger, LLC, New York, NY, 2019.), the Mammalian TrxR1 protein (PDB ID: 1H6V) was obtained from Protein Data Bank. The other subunits were deleted and only one monomer F was retained. Next, subunits $\mathrm{F}$ was assigned in sequence, hydrogen was added, ionization and tautomerism were adjusted, hydrogen bond distribution was optimized, water was removed, and structure was minimized. The LigPrep utility in Maestro 11.5 was used to perform ligand preparation applying OPLS2005 force field. Generation of tautomers and possible ionization states was mediated by Epik utility, followed by minimization of the resulting $3 \mathrm{D}$ comformations.

\subsubsection{Ligand Docking}

The docking task was completed on Discovery Studio Client 3.1. and the binding site of TrxR1 was defined as a docking sphere with dimensions X: 27.757, Y: 6.510, Z: 33.698 and a radius of $15 \AA$ A. Before using Flexible Docking Protocol, TrxR1 
1 protein was typed in CHARMm field force. 10 protein conformations were generated

2 with a maximum alteration of 8 residues.

3 Under the conformation method FAST, every ligand were generated 25 4 conformations with the value of $20 \mathrm{kcal}$ in the energy threshold. With all other 5 parameters as default, three ligands were docked into protein structure in the Flexible 6 Docking Protocol. For each poses, the distance between the compound's selenium 7 atom and the sulfur atom of either Cys497 or Cys498 was calculated by the distance 8 monitor in the Discovery Studio. For each ligand, average -CDocker energy and 9 average selenium-sulfur distance were calculated. The hydrogen bond interaction and $10 \pi-\pi$ stacking between the compounds and protein were analyzed.

\section{Statistical analysis}

13 Data were given as mean \pm SD of three independent experiments, graphs and 14 curve fitting were using origin Version 8.0 (OriginLab Corporation, Northampton, 15 USA). P value less than 0.05 was considered statistically significant.

\section{Acknowledgments}

18 This investigation was made possible through the financial support of National 19 Natural Science Foundation of China (Grant No: 21302065) and Shenzhen Fushan 20 Biological Technology Co., Ltd. China. 
3 [1] S. Bacchi, P. Palumbo, A. Sponta, M. F. Coppolino, Clinical pharmacology of. non-steroidal anti-Inflammatory drugs: a review, Antiinflamm Antiallergy Agents Med Chem. 11(1) (2012) 52-64.

[2] R. A. Moore, S. Derry, P. J. Wiffen, S. Straube. Effects of food on pharmacokinetics of immediate release oral formulations of aspirin, dipyrone, paracetamol and NSAIDs - a systematic review, Br. J. Clin. Pharmacol. 80 (3) (2015) 381-388.

[3] K. Miura, W. Fujibuchi, K. Ishida, T. Naitoh, H. Ogawa, T. Ando, N. Yazaki, K. Watanabe, S. Haneda, C. Shibata, I. Sasaki, Inhibitor of apoptosis protein family as diagnostic markers and therapeutic targets of colorectal cancer, Surg Today. 2011, 175-182.

[4] A.P. Fernandes, V. Gandin, Selenium compounds as therapeutic agents in cancer, Biochimica. et. Biophysica. Acta. 1850 (2015) 1642-1660.

[5] M. R. Smith, J. Manola, D.S. Kaufman, W.K. Oh, G.J. Bubley, P.W. Kantoff, Celecoxib versus placebo for men with prostate cancer and a rising serum prostate-specific antigen after radical prostatectomy and/or radiation therapy, J. Clin. Oncol. 24 (2006) 2723-2728.

[6] R.S. Pruthi, J.E. Derksen, D. Moore, C.C. Carson, G. Grigson, C. Watkins, E. Wallen, Phase II trial of celecoxib in prostate specific antigen recurrent prostate cancer after definitive radiation therapy or radical prostatectomy, Clin. Cancer. Res. 12 (2006) 2172-2177.

[7] D. Basudhar, G. Bharadwaj, R. Y. Cheng, S. Jain, S. Shi, J. L. Heinecke, R. J. Holland, L. A. Ridnour, V. M. Caceres, R. C. Spadari-Bratfisch, N. Paolocci, C. A. Velazquez-Martinez, D. A. Wink, K. M. Miranda, Synthesis and chemical and biological comparison of nitroxyl- and nitric oxide-releasing diazeniumdiolate-based aspirin derivatives, J. Med. Chem. 56 (2013) 7804-7820. 
[18] J. L. Williams, N. Nath, J. Chen, T. R. Hundley, J. Gao, L. Kopelovich, K. Kashfi,

2 B. Rigas, Growth inhibition of human colon cancer cells by nitric oxide

3 (NO)-donating aspirin is associated with cyclooxygenase-2 induction and

4 beta-catenin/T-cell factor signaling, nuclear factor-kappaB, and NO synthase 2

5 inhibition: implications for chemoprevention, Cancer Res. 63 (2003) 7613-7618.

[9] Y.A. Ammar, M.A. Salem, E.A. Fayed, M.H. Helal, M.S.A. El-Gaby, H. K.

7 Thabet, Naproxen derivatives: Synthesis, reactions, and biological applications,

8 Synth. Commun. 47(15) (2017) 1341-1367.

910] D. Plano, D. N. Karelia, M. K. Pandey, J. E. Spallholz, S. Amin, A. K. Sharma, 10 Design, synthesis, and biological evaluation of novel selenium (Se-NSAID)

11 molecules as anticancer agents, J. Med. Chem. 59 (2016) 1946-1959.

1211] D. Desai, N. Kaushal, U. H. Gandhi, R. J. Arner, C. D’Souza, G. Chen, H. Vunta, 13 K. El-Bayoumy, S. Amin, K. S. Prabhu, Synthesis and evaluation of the 14 anti-inflammatory properties of selenium-derivatives of celecoxib, Chem. Biol. 15 Interact. 188 (2010) 446-456.

1612] D. Desai, I. Sinha, K. Null, W. Wolter, M. A. Suckow, T. King, S. Amin, R. 17 Sinha, Synthesis and antitumor properties of selenocoxib-1 against rat prostate 18 adenocarcinoma cells, Int. J. Cancer. 127 (2010) 230-238.

1913] R. Alhasan, A. Kharma, P. Leroy, C. Jacob, C. Gaucher, Selenium Donors at the 20 Junction of Inflammatory Diseases, Curr. Pharm. Des. 25 (15) (2019) $21 \quad 1707-1716$.

2214] H. J. Reich, R. J. Hondal, Why nature chose selenium. ACS Chem. Biol. 11 23 (2016) 821-841.

2[15] Y. Pang, B. An, L. Lou, J. Zhang, J. Yan, L. Huang, X. Li, S. Yin, Design, 25 synthesis, and biological evaluation of novel selenium-containing 26 isocombretastatins and phen-statins as antitumor agents, J. Med. Chem. 60 (17) 27 (2017) 7300-7314.

28[16] Y. Yang, S. Deng, Q. Zeng, W. Hu, T. Chen, Highly stable selenadiazole 29 derivatives. induce bladder cancer cell apoptosis and inhibit cell migration and 
1 invasion through the activation of ROS-mediated signaling pathways, Dalton Trans. 45 (46) (2016) 18465-18475.

3 [17] A. Kunwar, B. Mishra, A. Barik, L.B. Kumbhare, R. Pandey, V.K. Jain, K.I. Priyadarsini, 3,3'-Diselenodipropionic acid, an efficient peroxyl radical scavenger and GPx mimic, protects erythrocytes (RBCs) from AAPH-induced hemolysis, Chem. Res. Toxicol. 20 (2007) 1482-1487.

[18] Y. Wang, J. Wallach, S. Duane, Y. Wang, J. Wu, J. Wang, A. Adejare, H. Ma, Developing selective histone deacetylases (HDACs) inhibitors through ebselen and analogs, Drug. Des. Dev. Ther. 11 (2017) 1369-1382.

[19] T. Cierpiał, J. Łuczak, M. Kwiatkowska, P. Kiełbasinśki, L. Mielczarek, K. Wiktorska, Z. Chilmonczyk, M. Milczarek, K. Karwowska, Organofluorine isoselenocyanate analogues of sulforaphane: synthesis and anticancer activity, ChemMedChem. 11 (21) (2016) 2398-2409.

[20] I. Lagunes, P. Begines, A. Silva, A.R. Galán, A. Puerta, M.X. Fernandes, I. Maya, J.G. Fernández-Bolaños, Ó. López, J.M. Padrón, Selenocoumarins as new multitarget antiproliferative agents: Synthesis, biological evaluation and in silico calculations, Eur. J. Med. Chem. 179 (2019) 493-501.

[21] X. He, M. Zhong, S. Li, X. Li, Y. Li, Z. Li, Y. Gao, F. Ding, D. Wen, Y. Lei, Y. Zhang, Synthesis and biological evaluation of organoselenium (NSAIDs-SeCN and $\mathrm{SeCF}_{3}$ ) derivatives as potential anticancer agents, Eur. J. Med. Chem. 208 (2020) 112864.

[22] R. J. Jariwalla, B. Gangapurkar, D. Nakamura, Differential sensitivity of various human tumour-derived cell types to apoptosis by organic derivatives of selenium, Br. J. Nutr. 101 (2009) 182-189.

[23] J. E. Spallholz, Free radical generation by seleniumcompounds and their prooxidant toxicity, Biomed. Environ. Sci. 10 (1997) 260-270.

[24] C. Storkey, M. J. Davies, J. M. White, C. H. Schiesser, Synthesis and antioxidant capacity of 5-selenopyanose derivatives, Chem. Commun. 47 (2011) 9693-9695. 
1[25] K. N. Sands, T. G. Back, Key steps and intermediates in the catalytic mechanism

2 for the reduction of peroxides by the antioxidant ebselen, Tetrahedron. 74 (38),

3 (2018) 4959-4967.

4[26] L. Liu, S. Li, X. Li, M. Zhong, Y. Lu, J. Yang, Y. Zhang, X. He, Synthesis of

5 NSAIDs-Se derivatives as potent anticancer agents, Med. Chem. Res. 27

$6 \quad$ (2018) 2071-2078.

7[27] Y. Nie, M. Zhong, S. Li, X. Li, Y. Zhang, Y. Zhang, X. He, Synthesis and

8 potential anticancer activity of some novel selenocyanates and diselenides, Chem.

$9 \quad$ Biodivers. 17(5) (2020) e1900603.

10[28] A.S. Hodage, P.P. Phadnis, A. Wadawale, K.I. Priyadarsini, V.K. Jain, Synthesis, 11 characterization and structures of 2-(3,5-dimethylpyrazol-1-yl) ethylseleno

12 derivatives and their probable glutathione peroxidase (GPx) like activity, Org.

13 Biomol. Chem. 9 (2011) 2992-2998.

14 [29] V. Nascimento, E. E. Alberto, D. W. Tondo, D. Dambrowski, M. R. Detty, F. 15 Nome, A. L. Braga, GPx-Like activity of selenides and selenoxides: experimental 16 evidence for the involvement of hydroxy perhydroxy selenane as the active species, 17 J. Am. Chem. Soc. 134 (1) (2012) 138-141.

18 [30] S. Ficht, L. Röglin, M. Ziehe, D. Breyer, O. Seitz, Direct carbodiimide-mediated 19 conjugation of carboxylates using pyridinium p-toluenesulfonate and tertiary 20 amines as additives, Synlett. 14 (2004) 2525-2528.

21 [31] P. Nikolaienko, M Rueping, Trifluoromethylselenolation of Aryldiazonium Salts: A Mild and Convenient Copper-Catalyzed Procedure for the Introduction of the $\mathrm{SeCF}_{3}$ Group, Chem. Eur. J. 22 (2016) 2620 - 2623.

[32] J. T. Pinto, R. Sinha, K. Papp, N. D. Facompre, D. Desai, K. El-Bayoumy, Differential effects of naturally occurring and synthetic organoselenium compounds on biomarkers in androgen responsive and androgen independent human prostate carcinoma cells, Int. J. Cancer. 120 (2007) 1410-1417.

[33] A. Ghose, J. Fleming, K. El-Bayoumy, P. R. Harrison, Enhanced sensitivity of human oral carcinomas to induction of apoptosis by selenium compounds: 
involvement of mitogen-activated protein kinase and Fas pathways, Cancer. Res. 61 (2001) 7479-7487.

[34] T. C. W. Chan, J. L. Wilkinson Berka, D. Deliyanti, D. Hunter, A. Fung, G. Liew, A. White, The role of reactive oxygen species in the pathogenesis and treatment of retinal diseases, Exp. Eye. Res. 201(2020) 108255.

[35] G. M. Gordillo, C. K. Sen, Revisiting the essential role of oxygen in wound healing, Am. J. Surg. 186 (2003) 259-263.

[36] K. R. Martin, J. C. Barrett, Reactive oxygen species as double-edged swords in cellular processes: low-dose cell signaling versus high-dose toxicity, Hum. Exp. Toxicol. 21 (2002) 71-75.

[37] J. E. Klaunig, Oxidative stress and cancer, Curr. Pharm. Des. 24 (40) (2018) 4771-4778.

[38] D. Pathania, M. Sechi, M. Palomba, V. Sanna, F. Berrettini, A. Sias, L. Taheri, N. Neamati, Design and discovery of novel quinazolinedione-based redox modulators as therapies for pancreatic cancer, Biochim. Biophys. Acta Gen. Subj. 1840 (1) (2014) 332-343.

[39] I. Rohn, N. Kroepfl, M. Aschner, J. Bornhorst, D. Kuehnelt, T. Schwerdtle, Selenoneine ameliorates peroxide-induced oxidative stress in C. elegans, J. Trace. Elem. Med. Bio. 55 (2019) 78-81.

[40] M. T. Melo, I. M. de Oliveira, I. Grivicich, T. N. Guecheva, J. Saffi, J. A. Henriques, R. M. Rosa, Diphenyl diselenide protects cultured MCF-7 cells against tamoxifen-induced oxidative DNA damage, Biomed. Pharmacother. 67 (2013) 329-335.

[41] S. Shaaban, A.M. Ashmawy, A. Negm, L.A. Wessjohann, Synthesis and biochemical studies of novel organic selenides with increased selectivity for hepatocellular carcinoma and breast adenocarcinoma, Eur. J. Med. Chem. 179 (2019) 515-526.

[42] D. Meriane, G. Genta-Jouve, M. Kaabeche, S. Michel, S. Boutefnouchet, Rapid identification of antioxidant compounds of Genista saharae coss. \& dur. By 
combination of DPPH scavenging assay and HPTLC-MS, Molecules. 19 (4) (2014) 4369-4379.

[43] R. Uddin, M.R. Saha, N. Subhan, H. Hossain, I.A. Jahan, R. Akter, A. Alam, HPLC-analysis of polyphenolic compounds in gardenia jasminoides and determination of antioxidant activity by using free radical scavenging assays, Adv. Pharmaceut. Bull. 4 (3) (2014) 273-281

[44] A. A. Bunaciu, A. F. Danet, Ş. Fleschin, H. Y. Aboul-Enein, Recent applications for in vitro antioxidant activity assay, Crit. Rev. Anal. Chem. 46 (5) (2016) 389-399.

[45] X. Tian, K.M. Schaich, Effects of molecular structure on kinetics and dynamics of the trolox equivalent antioxidant capacity assay with $\operatorname{ABTS}\left(\mathrm{t}^{*}\right)$, J. Agric. Food Chem. 61 (23) (2013) 5511-5519.

[46] M. Ibrahim, W. Hassan, J. Anwar, A.M. Deobald, J.P. Kamdem, D.O. Souza, J.B. Rocha, 1-(2-(2-(2-(1-Aminoethyl)phenyl)diselanyl)phenyl)ethanamine: an amino organoselenium compound with interesting antioxidant profile, Toxicol. In. Vitro. 28 (4) (2014) 524-530.

[47] J. L. Rose, K. C. Reeves, R. I. Likhotvorik, D. G. Hoyt, Base excision repair proteins are required for integrin-mediated suppression of bleomycin-induced DNA breakage in murine lung endothelial cells, J. Pharmacol. Exp. Ther. 321 (1) (2007) 318-326.

[48] A. Mira, E. M. Gimenez, A. D. Bolzan, M.S. Bianchi, D. M. Lopez-Larraza, Effect of thiol compounds on bleomycin-induced DNA and chromosome damage in human cells, Arch. Environ. Occup. Health. 68 (2) (2013) 107-116.

[49] B. Laffon, V. Valdiglesias, E. Pásaro, J. Méndez. The Organic selenium compound selenomethionine modulates bleomycin-induced DNA damage and repair in human leukocytes, Biol. Trace. Elem. Res. 133 (1) (2010) 12-19.

[50] V. Nascimento, E. E. Alberto, D. W. Tondo, D. Dambrowski, M. R. Detty, F. Nome, A. L. Braga, GPx-like activity of selenides and selenoxides: experimental evidence for the involvement of hydroxy perhydroxy selenane as the active species, J. Am. Chem. Soc. 134 (1) (2012) 138-141. 
1 [51] C.W. Nogueira, J.B.T. Rocha, Toxicology and pharmacology of selenium: emphasis on synthetic organoselenium compounds. Arch. Toxicol. 85 (11) (2011) 1313-1359.

[52] A.S. Hodage, P.P. Phadnis, A. Wadawale, K.I. Priyadarsini, V.K. Jain, Synthesis, characterization and structures of 2-(3,5-dimethylpyrazol-1-yl)ethylseleno derivatives and their probable glutathione peroxidase (GPx) like activity, Org. Biomol. Chem. 9 (8) (2011) 2992-2998.

[53] S. Gromer, L.A. Wessjohann, J. Eubel, W. Brandt, Mutational studies confirm。 the catalytic triad in the human selenoenzyme thioredoxin reductase predicted by molecular modeling, Chem biochem 7 (2006) 1649-1652.

[54] W. Brandt, L.A. Wessjohann, The functional role of selenocysteine (Sec) in the catalysis mechanism of large thioredoxin reductases: proposition of a swapping catalytic triad including a Sec-His-Glu state, Chembiochem 6 (2005) 386-394.

[55] T. Sandalova, L. Zhong, Y. Lindqvist, A. Holmgren, G. Schneider, Threedimensional structure of a mammalian thioredoxin reductase: implications for mechanism and evolution of a selenocysteine-dependent enzyme, Proc. Natl. Acad. Sci. U. S. A. 98 (2001) 9533-9538.

[56] S. Shaaban, Amr Negm, A.M. Ashmawy, D.M. Ahmed, L.A. Wessjohann, Combinatorial synthesis, in silico, molecular and biochemical studies of tetrazole-derived organic selenides with increased selectivity against hepatocellular carcinoma, Eur. J. Med. Chem. 122 (2016) 55-71.

[57] S. A. Arafa, A. H. Abdelazeem, H. H. Arab, H. A. Omar, OSU-CG5, a novel energy restriction mimetic agent, targets human colorectal cancer cells in vitro, Acta Pharmacol. Sin. 35 (2014) 394-400.

[58] H. A. Omar, S. A. Arafa, I. A. Maghrabi, J. R. Weng, Sensitization of hepatocellular carcinoma cells to Apo21/TRAIL by a novel Akt/NF- $\kappa$ B signalling Inhibitor, Basic Clin. Pharmacol. Toxicol. 114 (2014) 464-471.

[59] A.R. Verma, M. Vijayakumar, C.V. Rao, C.S. Mathela, In vitro and in vivo antioxidant properties and DNA damage protective activity of green fruit of Ficus glomerata, Food. Chem. Toxicol. 48 (2) (2010) 704-709. 
1 [60] A.B.A. El-Gazzar, M.M. Youssef, A.M.S. Youssef, A.A. Abu-Hashem, F.A. Badria, Design and synthesis of azolopyrimidoquinolines, pyrimidoquinazolines as anti-oxidant, anti-inflammatory and analgesic activities, Eur. J. Med. Chem. 44 (2009) 609-624.

5 [61] N. M. Giles, G. I. Giles, J. E. Holley, N. J. Gutowski, C. Jacob, Targeting oxidative 6 stress-related diseases: organochalcogen catalysts as redox sensitizers, Biochem. Pharmacol. 66 (2014), 2021-2028.

8 